\title{
SOEP
}

SOEPpapers
On Muldidicopinany Panel Data Reseach

SOEPDa Crs

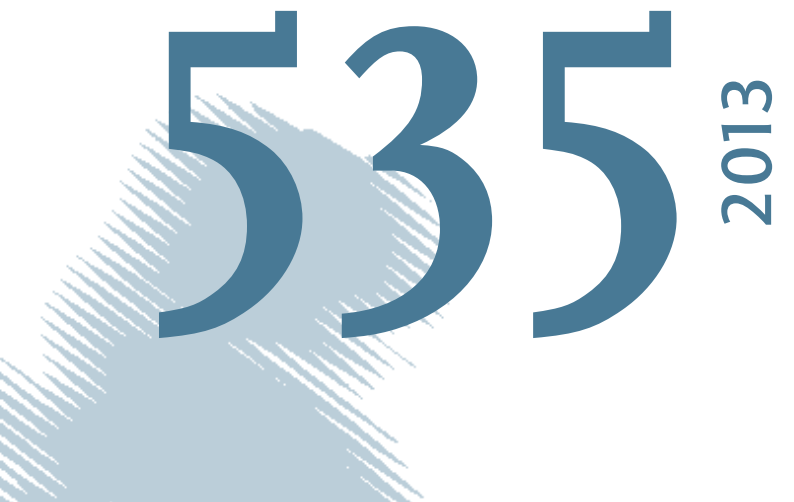

$\frac{m}{0}$

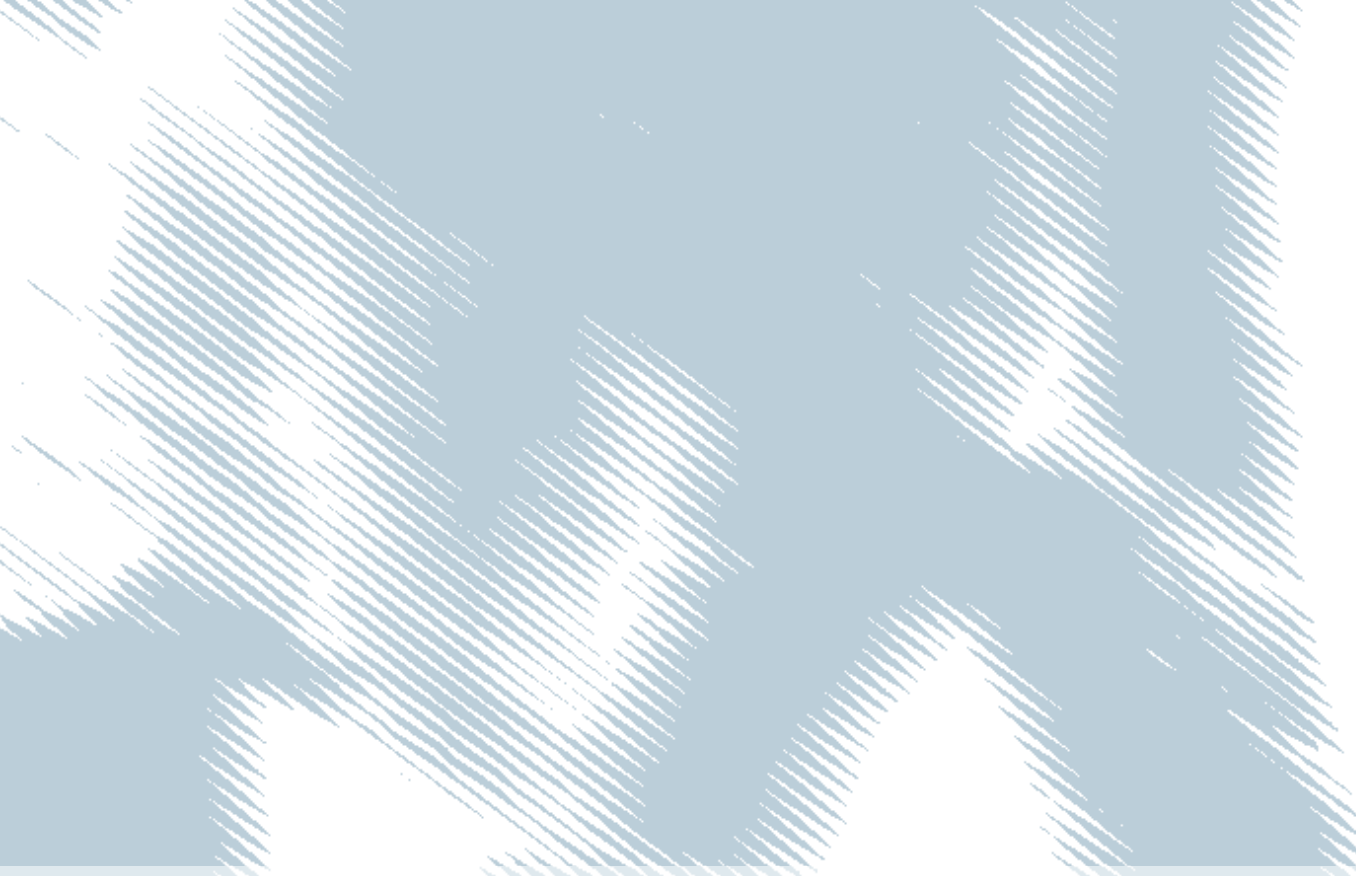

\section{Exposure to Television and Individual Beliefs: Evidence from a Natural Experiment}




\section{SOEPpapers on Multidisciplinary Panel Data Research}

at DIW Berlin

This series presents research findings based either directly on data from the German SocioEconomic Panel Study (SOEP) or using SOEP data as part of an internationally comparable data set (e.g. CNEF, ECHP, LIS, LWS, CHER/PACO). SOEP is a truly multidisciplinary household panel study covering a wide range of social and behavioral sciences: economics, sociology, psychology, survey methodology, econometrics and applied statistics, educational science, political science, public health, behavioral genetics, demography, geography, and sport science.

The decision to publish a submission in SOEPpapers is made by a board of editors chosen by the DIW Berlin to represent the wide range of disciplines covered by SOEP. There is no external referee process and papers are either accepted or rejected without revision. Papers appear in this series as works in progress and may also appear elsewhere. They often represent preliminary studies and are circulated to encourage discussion. Citation of such a paper should account for its provisional character. A revised version may be requested from the author directly.

Any opinions expressed in this series are those of the author(s) and not those of DIW Berlin. Research disseminated by DIW Berlin may include views on public policy issues, but the institute itself takes no institutional policy positions.

The SOEPpapers are available at

http://www.diw.de/soeppapers

\section{Editors:}

Jürgen Schupp (Sociology, Vice Dean DIW Graduate Center)

Gert G. Wagner (Social Sciences)

Conchita D'Ambrosio (Public Economics)

Denis Gerstorf (Psychology, DIW Research Director)

Elke Holst (Gender Studies, DIW Research Director)

Frauke Kreuter (Survey Methodology, DIW Research Professor)

Martin Kroh (Political Science and Survey Methodology)

Frieder R. Lang (Psychology, DIW Research Professor)

Henning Lohmann (Sociology, DIW Research Professor)

Jörg-Peter Schräpler (Survey Methodology, DIW Research Professor)

Thomas Siedler (Empirical Economics)

C. Katharina Spieß (Empirical Economics and Educational Science)

ISSN: 1864-6689 (online)

German Socio-Economic Panel Study (SOEP)

DIW Berlin

Mohrenstrasse 58

10117 Berlin, Germany

Contact: Uta Rahmann | soeppapers@diw.de 


\title{
Exposure to Television and Individual Beliefs: Evidence from a Natural Experiment
}

\author{
Tanja Hennighausen* \\ University of Mannheim and Centre for European Economic Research (ZEW)
}

This version: October 2012

First version: February 2011

\begin{abstract}
Does the information provided by mass media have the power to persistently affect individual beliefs about the drivers of success in life? To answer this question empirically, this contribution exploits a natural experiment on the reception of West German television in the former German Democratic Republic. After identifying the impact of Western television on individual beliefs and attitudes in the late 1980s, longitudinal data from the German Socio-Economic Panel is used to test the persistence of the television effect on individual beliefs during the 1990s. The empirical findings indicate that Western television exposure has made East Germans more inclined to believe that effort rather than luck determines success in life. Furthermore, this effect still persists several years after the German reunification.
\end{abstract}

Key Words: media, beliefs, East Germany, SOEP

JEL-Classification: D78, D83, H89, P39

Acknowledgement: This paper has benefitted from comments by Christina Gathmann, Christian Traxler, Roland Vaubel, my colleagues at ZEW and University of Mannheim as well as the participants of the Public Finance Workshop in Mannheim, the Congress of the International Institute of Public Finance in Ann Arbor, the Annual Meeting of the Verein für Socialpolitik in Frankfurt, the Second World Congress of the Public Choice Societies in Miami, and the Spring Meeting of Young Economists in Mannheim. Moreover, I thank Sebastian Zilch for his valueable research assistance.

\footnotetext{
*University of Mannheim

L7, 3-5

Phone: $\quad+496211811818$

D-68131 Mannheim, Germany

Fax: $\quad+496211811814$

E-mail: hennighausen@uni-mannheim.de
} 


\section{Introduction}

Individual preferences for redistribution cannot fully be explained by pure self-interest but are also affected by fairness considerations. Voters usually want to reduce inequality as far as it is driven by factors that are beyond individual control (such as luck or social conditions) but reward individual effort. Individuals, however, do not exactly know to what extent a certain level of inequality reflects differences in individual effort or is a consequence of other factors. Therefore, people have to form and rely on beliefs about the relative importance of effort as a determinant of success in life, for instance, when voting on redistributive policies.

In line with that, these beliefs are both related to preferences for redistribution (e.g. Alesina and Giuliano, 2009; Corneo and Grüner, 2002; Fong, 2001) and actual policies such as the size and structure of the welfare state (Alesina and Glaeser, 2004). In contrast to their policy relevance, our knowledge about individual belief formation is still incomplete.

The literature on belief formation suggests that individuals use available information from various sources to learn about the rewards to effort and form their corresponding beliefs about the drivers of success. They use, for instance, their personal experience or family history to learn about the relative importance of effort (Piketty, 1995; Di Tella et al., 2007; Giuliano and Spilimbergo, 2009).

Moreover, Alesina and Glaeser (2004) argue that observable differences in beliefs of Americans and Europeans do not just reflect differences in personal experience but are rather a result of political indoctrination. Convincing empirical evidence isolating the impact of indoctrination (such as exposure to Marxist ideas) on beliefs about the drivers of success is still missing. This contribution wants to close this gap by analyzing if political indoctrination via mass media has a persistent impact on beliefs.

To answer this question empirically, I test whether the exposure to West German television and thereby to Western world views and ideologies has affected East Germans' beliefs. The focus on the case of the former German Democratic Republic (GDR) has at least two advantages: First, state-controlled mass media was used to promote the ideologies and world views of both German states. The predominant ideology differed considerably between Communist and Western states and also comprised assumptions about the determinants of success in life and social mobility.

Second, by focusing on the GDR, I can exploit a natural experiment on the reception of 
Western television broadcasts. Approximately 15 percent of the population living in the Southeast and the Northeast of the GDR could not receive Western television broadcasts. In these regions, the strength of the over-the-air television signal was too low to receive these broadcasts either because the nearest West German transmitter station was too far away or because the area was surrounded by mountains. Therefore, the population in these regions constitutes a natural counterfactual to the majority of GDR citizens who were already exposed to Western television before reunification. Moreover, since the decision to watch West German broadcasts was partly exogenous for each GDR citizen (given his or her place of residence), it is possible to overcome the self-selection problem common in empirical works on media effects. ${ }^{1}$

The empirical analysis draws on two different data sets. First, I use survey data collected in the GDR during the late 1980s to test whether the differential access to Western television is reflected in East Germans' beliefs before reunification. The second part of the analysis is devoted to the persistence of the Western television effect during the 1990s. For that purpose I exploit longitudinal data from the German Socio-Economic Panel (SOEP). Overall, the findings indicate that exposure to Western television has made East Germans more inclined to believe that effort rather than luck determines success in life. Furthermore, the effect of West German television on East Germans' beliefs seems to have persisted until ten years after reunification.

This paper adds to the literature both on belief formation and on media. It is closely related to empirical studies on the role of television which indicate that values, attitudes or behavior are affected by information on different ways of life and world views as presented in entertainment programs (e.g. soap operas or movies). Recent examples are cable television in rural India which has improved women's status by offering information about urban life (Jensen and Oster, 2009) or access to national telenovelas in Brazil presenting mostly small and wealthy families which has increased divorce rates (Chong and La Ferrara, 2009) and reduced fertility (Chong et al., 2008).

So far, literature has mostly focused on the immediate impact of media on attitudes and behavior. I provide further evidence indicating that television has also the power to

\footnotetext{
${ }^{1}$ Empirical approaches which do not use any exogenous source of variation in media access to measure media effects usually face a self-selection problem: It is not clear whether a person has a certain attitude because of a particular media source or whether the decision to utilize a media source is actually driven by prior attitudes.
} 
persistently affect certain attitudes.

This paper further contributes to literature by relating a permanent exposure to considerably different and biased media sources to beliefs about drivers of success. By this, it offers insights into the role of political indoctrination for the formation of individual beliefs (as suggested by Alesina and Glaeser, 2004).

Recently, the impact of Communism on individuals' attitudes or preferences has received much attention among economists. By focusing on the case of Germany, this literature usually interprets differences between East and West Germans as a result of different socialization during the 40 years of separation (e.g. Alesina and Fuchs-Schündeln, 2007; Heineck and Süssmuth, 2010). Socialization, however, is a broad and rather imprecise concept that encompasses all differences in general life experience. Attempts to identify the impact of specific aspects of socialization on individual beliefs (or other attitudes) have not been undertaken before. This paper isolates the effect of indoctrination by state-controlled television on beliefs about the drivers of success from the broader aspect of different socialization and life experience in both parts of Germany. Bringing forward the argument that life experience of the population should not differ systematically between regions with and without Western television reception, differences between the two groups can be attributed to the impact of Western television and the set of information provided therein.

The remainder of this paper is organized as follows: The second section provides institutional facts about television in the GDR. The subsequent section offers some insights into the role of television for belief formation. Section 4 is devoted to the discussion of the identification strategy, the empirical approach and the data. The results are presented in section 5 , followed by a discussion of potential confounding factors and further tests in section 6 . Concluding remarks are offered in section 7 .

\section{Institutional background: Television in the GDR}

Following World War II, Germany was separated by the allied forces and in 1949 two independent German states were founded. While these states did not differ substantially before their separation (Alesina and Fuchs-Schündeln, 2007), 40 years of political and economic division led to a strong divergence in living standards. GDR citizens suffered from economic scarcity and political repression by the state authorities. In November 1989 the unexpected 
opening of the inner-German border by the GDR regime resulted in the merging of the two German states, with the monetary union in July 1990 and the political reunification in October 1990.

In both German states, the first television broadcasting corporations were founded in 1952 (e.g. Meyen, 2003). In West Germany, two public corporations were established, the First German Television (ARD) with its constituent regional broadcasting institutions and in 1963 the Second German Television (ZDF). The state-controlled television of the GDR consisted of two channels, DFF 1 and DFF 2, which started their regular broadcasting in 1956 and 1969. In February 1990 the GDR parliament declared East German television to be politically independent. Finally, in the course of political reunification, GDR television was integrated into the system of the Federal Republic of Germany (FRG) though Eastern and Western states are served by regional channels of their own.

In 1955 only 1.2 percent of the GDR households had a television set. The availability of television, however, strongly increased in the 1960s and 1970s. ${ }^{2}$ In 1988 about 96 of 100 GDR households had at least one television set (GDR Statistical Office, various years).

The majority of GDR citizens was able to receive West German television (i.e. usually the main public stations ARD, ZDF, and a regional broadcast station) already before reunification and had, by this, access to different information about the West and the way of life there but also on the situation in the GDR.

However, approximately 15 percent of the GDR population living in the Northeast around Greifswald and in the Southeast around Dresden (called "Valley of the Clueless") could not receive Western television (see also Etzkorn and Stiehler, 1998). In these regions the strength of the over-the-air-signal of West German television transmitter stations was below a certain threshold required for West German television reception either due to geographical or topological reasons (i.e. these regions were either too far away from the next transmitter station or surrounded by mountains).

Figure 1 illustrates the reception of the FRG television channel ARD within the GDR as well as the 15 administrative districts of the GDR. The dark areas mark the two regions without ARD reception that coincide almost perfectly with the district of Dresden and parts of the districts Neubrandenburg and Rostock.

\footnotetext{
${ }^{2}$ Already in 196548.5 percent of all households had a television set. The share of households with television further increased to 81.6 percent in 1975 and 93.4 percent in 1985 (GDR Statistical Office, various years).
} 

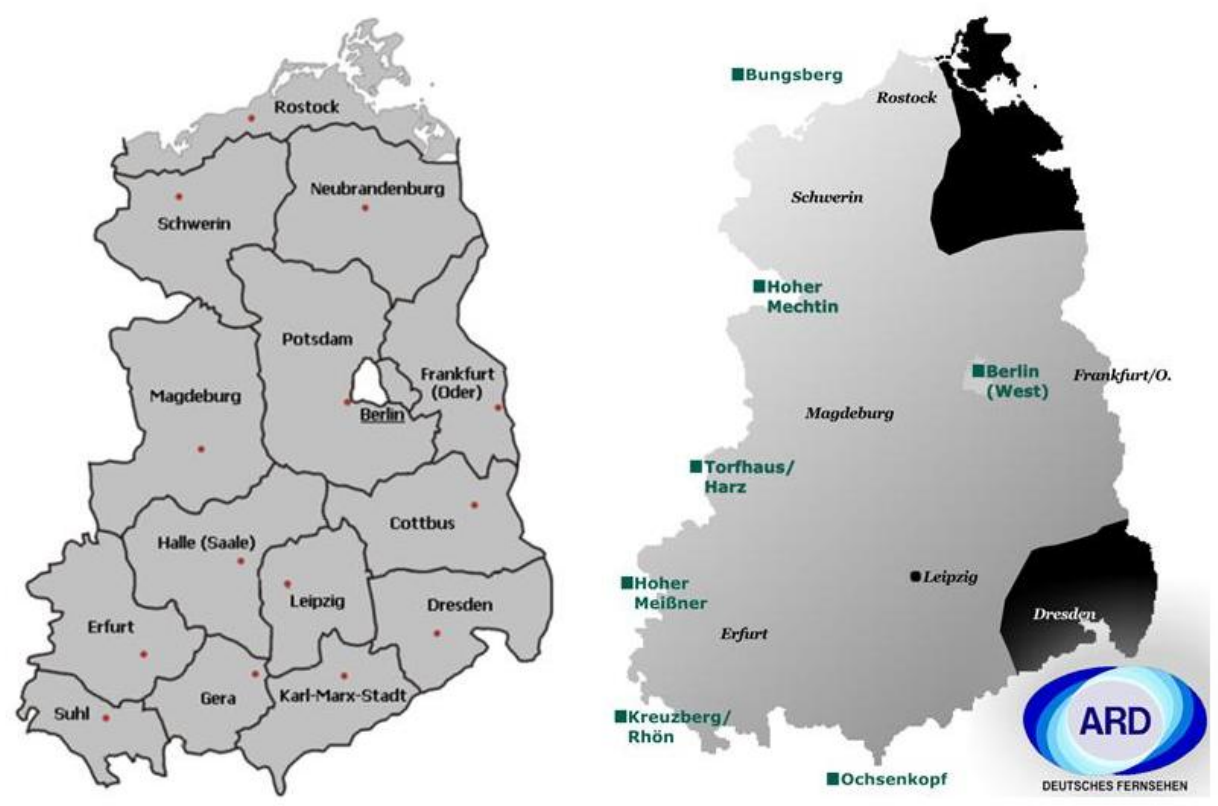

The figure shows the GDR administrative districts (left) and the access to the West German television channel ARD in the GDR (right). The quadratic dots indicate West German transmitters, and the dark areas are the regions without access to West German television.

Table 1: Self-Reported frequency of Watching West German television (by DISTRICT)

\begin{tabular}{lcccccc}
\hline \hline \multirow{2}{*}{ District } & \multicolumn{5}{c}{ How often do you watch FRG television? } \\
\hline Berlin & Mean & Std.Dev. & Median & Never (in \%) & Obs. & missings \\
Cottbus & 1.5 & 0.78 & 1 & 0.24 & 416 & 3 \\
Dresden & 1.28 & 0.72 & 1 & 1.67 & 60 & 0 \\
Erfurt & $\mathbf{4 . 3 0}$ & $\mathbf{1 . 2 3}$ & $\mathbf{5}$ & $\mathbf{6 3 . 5 2}$ & $\mathbf{7 3 4}$ & $\mathbf{5 0}$ \\
Karl-Marx-Stadt & 1.40 & 0.76 & 1 & 1.23 & 641 & 8 \\
Leipzig & 1.51 & 0.82 & 1 & 2.05 & 622 & 11 \\
Magdeburg & 1.85 & 1.18 & 1 & 5.42 & 274 & 3 \\
Schwerin & 1.35 & 0.72 & 1 & 1.09 & 542 & 7 \\
Tow often & 1.47 & 0.91 & 1 & 1.04 & 191 & 1
\end{tabular}

How often do you watch West German television? (1) every day, (2) more than once a week, (3) once a week, (4) less than once a week, (5) never.Source: GDR survey data collected between November 1988 and February 1989 (provided by the Zentralinstitut für Jugendforschung).

The subsequent empirical analysis relies on the assumption that East Germans who had the opportunity to watch West German television actually did watch it, while those without access to Western television did not. Table 1 presents survey data on the frequency of watching West German television collected in 1988/89 in eight of the fifteen GDR-districts. 
The self-reported intensities of FRG television reception indicate its popularity. ${ }^{3}$ The average respondent watched FRG broadcasts almost every day. Those from the Dresden-district, however, watched Western television significantly less often than those living in other parts of the GDR. Overall, 63.5 percent of the respondents living in the district of Dresden declared that they never watch Western television.

\section{The role of Western television in belief formation}

In general, individuals have only an imperfect knowledge about the true relationship between effort and success in life. Consequently, they have to rely on beliefs regarding this relationship, for instance, when voting on redistributive policies or deciding on how much effort to put into work. To form these beliefs, individuals use (noisy) signals they receive from different sources (ranging from own experience and learning from earlier generations to information provided by others).

So far, both theoretical and empirical studies show that personal experience matters for belief formation (e.g. Piketty, 1995; Giuliano and Spilimbergo, 2009; Di Tella et al., 2007). Alesina and Glaeser (2004) provide an alternative explanation for the observed heterogeneity in beliefs between the United States and Europe. The authors point out that this heterogeneity does not necessarily reflect differences in experience or incentives ${ }^{4}$ but are rather a result of political indoctrination. While Europeans have long been exposed to Marxist ideas about the class system, right-wing politicians in the United States had more power to push their own way of understanding economic opportunity.

Several empirical studies comparing popular beliefs and attitudes toward the welfare state in former socialist countries and Western democracies indeed find systematic and persistent differences (Corneo and Grüner, 2002; Suhrcke, 2001). In the case of Germany, these dif-

\footnotetext{
${ }^{3}$ West German television programs were very popular among GDR citizens both as a source of political information and entertainment. The regime had been well aware of this popularity. In the 1960s, the authorities took several measures to prevent the reception of West German television (e.g. removing antennas directed to the West). In the 1970s, however, Erich Honecker stated that everyone could use Western media sources as he or she wanted to. At the latest in the 1980s, most East Germans watched FRG television (Stiehler, 2001).

${ }^{4}$ Alesina and Angeletos (2005) argue that any preexisting differences in beliefs between countries can be manifested since they result in different welfare policies with different implications on incentives to exert effort. This can explain why systematical differences in beliefs about the role of effort in income generation can persist between the United States and European countries. Benabou and Tirole (2006) further argue that individuals need to believe in a "just world" to motivate themselves or their children toward effort. Therefore, they systematically distort their beliefs by (subconsciously) ignoring information indicating the opposite.
} 
ferences are particularly obvious: even several decades after reunification, East and West Germans entertain different beliefs and preferences for state intervention (e.g. Alesina and Fuchs-Schündeln, 2007; Heineck and Süssmuth, 2010). In line with Marxist ideas about limited opportunities of upward social mobility in the working class, East Germans are more inclined to believe that external forces (such as social conditions and connections) determine individual fortunes than West Germans. These persistent differences are widely interpreted as an overall consequence of socialization such as experience of life in a communist regime and a planned economy as well as exposure to the Marxist-Leninist ideology in schools, at the work-place and in mass media. Due to a considerable degree of centralization in virtually all policy fields, there should be no systematic differences in general life experience or indoctrination in schools or at work among GDR citizens. In one respect, however, the experience of East Germans differed: while people living in the Northeast and Southeast of the country could only watch state-controlled GDR television, most people had also access to West German television broadcasts and the set of information provided therein.

Television as a powerful tool for politicians to disseminate their ideological ideas was used for political indoctrination in the GDR. Consequently, the set of information provided by both Western and Eastern television broadcasts had been biased in favor of the respective world views and ideologies and, thus, differed considerably during the cold war.

Empirical evidence indicates that biased reporting by television affects attitudes and voting behavior. The choice of television news by individuals in the Islamic world correlates with their attitudes toward the United States (Gentzkow and Shapiro, 2004): Persons watching $\mathrm{Al}$ Jazeera are more skeptical toward the United States than those watching CNN International. ${ }^{5}$ Moreover, politically biased television broadcasts affect voting behavior (e.g. DellaVigna and Kaplan (2007) for the U.S. and Enikolopov et al. (2011) for Russia). Existing evidence for the GDR, however, does not indicate a successful indoctrination of GDR citizens by biased television reports. Kern and Hainmueller (2009) find that access to Western television actually increased the satisfaction with life in the GDR in the late 1980s. Despite a more critical view on the situation in the GDR, the availability of Western television seemed to stabilize the regime. The authors argue that Western television entertained GDR citizens and, by this, made their life more bearable. The relevance of West German entertainment

\footnotetext{
${ }^{5}$ This finding, however, does not allow any conclusions about the causal impact of exposure to biased mass media on attitudes since the decision to watch Al Jazeera or CNN International is likely to be driven by a person's prior attitudes toward the United States.
} 
programs as free time activity has been emphasized by several media studies focusing on East Germany (e.g. Meyen, 2002).

As indicated by recent empirical studies, entertainment programs have the power to change individual attitudes or behavior (an extensive survey is provided by Prat and Strömberg, 2011). Movies or soap operas expose individuals to information on different ways of life and the characters presented in these programs serve as role models. Jensen and Oster (2009) show that access to cable television and, thus, the opportunity to learn about the life and status of urban women as presented in soap operas has lowered the acceptability of domestic violence against women and son preferences in rural India. Additional evidence is based on the reception of famous Brazilian telenovelas which present families that are usually smaller and wealthier than the average family in Brazil. Individuals who are exposed to this information seem to adapt the favorable assessment of smaller family sizes since the fertility is lower (Chong and La Ferrara, 2009) and divorce rates are higher (Chong et al., 2008) in areas where these telenovelas are available.

Given the popularity of West German entertainment programs among the population of the GDR and motivated by recent findings regarding the role of television, I expect that West German television broadcasts affected East Germans' beliefs about the drivers of success in a comparable way. By watching Western entertainment programs, GDR citizens were exposed to world views, values and ideologies common in the West. ${ }^{6}$ The everyday confrontation with a different world view and ideology is assumed to make people absorb at least part of it. This should also be true for beliefs about the relative merits of effort as a determinant of success since the Marxist and Capitalist ideology differ considerably in this issue. Though access to West German television broadcasts does not imply a uniform effect of exposure to Western ideas and ideology, on average East Germans who received the information might be expected to entertain beliefs that are different from those citizens who had only access to the views provided by GDR television.

Moreover, beliefs that have been built up over decades are likely to remain relatively stable over time (Giuliano and Spilimbergo, 2009). Thus, differences between East Germans

\footnotetext{
${ }^{6}$ While objective information about the possibilities of upward mobility can be also presented in the news, East Germans might even learn more about - and probably adopt - Western ideas about social mobility and income generation by watching movies or soap operas in which characters get promoted due to their effort or experienced upward mobility e.g. during the economic miracle in the 1950s and 1960s ("Wirtschaftswunder"). In addition to West German productions also U.S. soap operas (e.g. Denver Clan and Dallas) had been very popular among GDR citizens (Hesse, 1988).
} 
with and without access to West German television should not diminish very quickly once everyone has had access to these broadcasts.

\section{Empirical strategy and data}

A naïve econometric approach to analyze how television affects individual beliefs would be to regress these beliefs on (self-reported) television watching. However, the choice of a certain television broadcast may not be exogenous: if a person agrees widely with the socialist ideology and is, thus, more inclined to share the predominant beliefs he or she might avoid Western television broadcasts. In this case, any correlation between Western television and beliefs cannot be interpreted as a causal effect. To overcome this self-selection problem, I exploit the exogenous variation in regional availability of West German television broadcasts in the GDR. Basically, my empirical strategy is to compare the beliefs of GDR citizens who had access to Western television already before reunification with those who had not. A similar approach has recently been applied by Bursztyn and Cantoni (2012) and Kern and Hainmueller (2009). ${ }^{7}$

In a first step, I use survey data collected by the central institute for youth research ("Zentralinstitut für Jugendforschung") between November 1988 and February 1989 in eight of the fifteen GDR districts. ${ }^{8}$ This survey covers mostly teenagers and young adults employed in preselected production units. ${ }^{9}$ The data contains information on a range of attitudes and beliefs as well as on socioeconomic characteristics which allow to measure the impact of several decades of exposure to Western television on East Germans beliefs. Based on this

\footnotetext{
${ }^{7}$ Kern and Hainmueller limit their analysis on the late 1980s and offer, thus, no information on the persistence of the Western television effect on particular attitudes. Bursztyn and Cantoni relate advertisement in West German television during the 1980s to East Germans' consumption choices after reunification. While Western television does not affect overall consumption levels, the intensity of advertisement during the 1980s is reflected in consumption of certain categories of goods in 1993 for East Germans who had access to FRG broadcasts.

${ }^{8}$ These districts are Berlin, Cottbus, Dresden, Erfurt, Karl-Marx-Stadt, Leipzig, Magdeburg, and Schwerin.

${ }^{9}$ Several GDR survey data sets have been collected by the GESIS-ZA and made available for social research. In general, one might be skeptical about the reliability of data collected by GDR institutions as the respondents may not have revealed their true opinions due to fear of political prosecution or disadvantages for their future life or career. However, the researchers had guaranteed anonymity by distributing the questionnaires to a group of participants, gave them the opportunity to answer them on their own and collected them altogether afterwards (e.g. Stiehler, 1998; Meyen, 2003). This process seemed to work as many respondents gave critical answers e.g. to questions concerning the regime and authorities.
} 
data, I estimate the following reduced form equation:

$$
Y_{i d}=\beta_{0}+\beta D_{d}+\gamma X_{i d}+\delta G_{d}+\epsilon_{i d}
$$

where the outcome variable $Y_{i d}$ denotes the belief of an individual $i$ living in district $d .{ }^{10}$ This dummy variable equals one for respondents who believe that a high level of effort pays off for the society and also for themselves, and is zero otherwise. The main variable of interest, $D_{d}$, indicates whether the respondent lives in a district with West German television reception. Since the area of the GDR without access to Western television has coincided almost perfectly with the district of Dresden, $D_{d}$ is equal to a Dresden-dummy. ${ }^{11}$ Furthermore, $X_{i d}$ includes a set of individual-level controls and $G_{d}$ captures several district characteristics.

After focusing on the impact of differential access to Western television on East Germans' beliefs in the late 1980s, the second part of the empirical analysis is devoted to its persistence during the 1990s. For that purpose, I make use of data from the German Socio-Economic Panel. The SOEP is a longitudinal study of private households designed to be representative for the German population. While for West Germany the survey has been conducted annually since 1984, the former GDR was covered the first time in June 1990. The "East-sample" includes 2,179 households with 4,453 members who were surveyed in 1990 (Wagner et al., $2007) \cdot{ }^{12}$

I use data from this sample collected during the 1990s to estimate the following equation:

$$
Y_{i d t}=\beta_{0}+\beta D_{d, 1990}+\gamma X_{i d t}+\delta G_{d t}+\mu_{t}+\epsilon_{i d t},
$$

where $Y_{i d t}$ is the belief an individual $i$ living in district $d$ holds in year $t, X_{i d t}\left(G_{d t}\right)$ denotes a set of individual-level (district-level) controls, $\mu_{t}$ includes year fixed effects and Western television availability in district $d$ before reunification is indicated by $D_{d, 1990}$. This variable equals one if Western television reception was not already possible during the German separation, and zero otherwise. Respondents are assigned into groups with and without Western television based on their place of residence at the level of regional planning units

\footnotetext{
${ }^{10}$ More detailed information on the variables and the corresponding survey questions is available in Table 17 in the appendix.

${ }^{11}$ Besides the district of Dresden also parts of the districts Rostock and Neubrandenburg had no access to Western television (see Figure 1). For the latter, however, no survey data is available.

${ }^{12}$ Further information on the SOEP is available online at http://www.diw.de/en/diw_02.c.222508.en/ soep_overview.html.
} 
(Raumordnungsregionen) in June $1990 .{ }^{13}$ In the baseline regression $D_{d, 1990}$ is equal to one if an individual lived in the former district of Dresden i.e. the regional planning units "Dresden" and "Oberlausitz" in 1990 and, thus, most likely had no access to Western television. Consequently, the treatment status of an individual is defined by his or her place of residence before reunification and does not change over time (i.e. is independent of an individual's place of residence after 1990). ${ }^{14}$

The questions referring to individual beliefs were asked in the survey waves from 1994 to 1996 and in 1999. The dependent variable LUCK equals one if the respondent claims that achievement in life is mainly a matter of luck, and is zero otherwise.

Table 2: Summary statistics - Dependent VARIABle

\begin{tabular}{|c|c|c|c|c|c|c|c|c|c|c|}
\hline & \multicolumn{3}{|c|}{$\begin{array}{c}(1) \\
\text { Whole sample }\end{array}$} & \multicolumn{3}{|c|}{$\begin{array}{c}(2) \\
\text { Dresden }\end{array}$} & \multicolumn{3}{|c|}{$\begin{array}{c}(3) \\
\text { Other parts of the GDR }\end{array}$} & \multirow[t]{2}{*}{$\begin{array}{l}(2)-(3) \\
\text { Difference }\end{array}$} \\
\hline & Mean & $\begin{array}{l}\text { Standard } \\
\text { Dev. }\end{array}$ & Obs. & Mean & $\begin{array}{l}\text { Standard } \\
\text { Dev. }\end{array}$ & Obs. & Mean & $\begin{array}{l}\text { Standard } \\
\text { Dev. }\end{array}$ & Obs. & \\
\hline $1988 / 89$ & \multicolumn{10}{|c|}{ Effort pays off } \\
\hline \multicolumn{11}{|c|}{ Luck matters for success } \\
\hline 1994-99 & 0.221 & 0.415 & 13204 & 0.250 & 0.433 & 1385 & 0.218 & 0.413 & 11819 & $0.0323^{* * *}$ \\
\hline 1994 & 0.206 & 0.404 & 3085 & 0.251 & 0.434 & 370 & 0.210 & 0.408 & 3455 & $0.0458^{* *}$ \\
\hline 1995 & 0.194 & 0.395 & 3014 & 0.243 & 0.429 & 342 & 0.199 & 0.399 & 3356 & $0.0489^{* *}$ \\
\hline 1996 & 0.186 & 0.389 & 2957 & 0.218 & 0.414 & 353 & 0.189 & 0.392 & 3310 & $0.0325^{*}$ \\
\hline 1999 & 0.2909 & 0.454 & 2763 & 0.2909 & 0.455 & 320 & 0.2906 & 0.454 & 3083 & -0.0004 \\
\hline
\end{tabular}

Notes: $* * * / * * / *$ denotes significance of the differences of mean values between both groups at the $1 \% / 5 \% / 10 \%$ level.

The summary statistics presented in Table 2 already indicate that at the end of the 1980s persons living in Dresden were less inclined to believe that effort determines success in life. In the 1990s the differences between the two groups are smaller but individuals without access to Western television before reunification were still more likely to ascribe success to

\footnotetext{
${ }^{13}$ Regional planning units are smaller than the regions at the NUTS 2-level but bigger than counties. In 1990 Germany had 97 regional planning units with 23 of them located in East Germany.

${ }^{14}$ I have dropped persons living in households which had moved since 1988 to avoid an erroneous assignment of respondents. Furthermore, respondents who lived in 1990 in the regional planning unit "GreifswaldStralsund" are not included in the baseline regressions since they had only partly access to Western television before reunification.
} 
factors exogenous to the individual (e.g. luck) than to behavior. ${ }^{15}$

\section{Identifying assumptions}

The identifying assumption is that individuals in regions with access to West German television would not have been different from those without access if they had not had Western television. Basically, this implies that the inhabitants of the Dresden-district should be on average comparable to other GDR citizens except for the differential access to Western television. I discuss this in more detail below.

Table 3: Electoral outcomes in the Reichstag Election 1932 By Constituency

\begin{tabular}{lccccccc}
\hline \multicolumn{1}{c}{ Electoral district } & Voter turnout & \multicolumn{5}{c}{ Party vote share } \\
& & KPD & SPD & Zentrum & DVP & DNVP & NSDAP \\
\hline Berlin & 80.6 & 33.4 & 27.9 & 4.6 & 0.4 & 6.7 & 24.6 \\
Chemnitz-Zwickau & 89.2 & 19.6 & 22.4 & 0.7 & 0.8 & 3.8 & 47 \\
Dresden-Bautzen & $\mathbf{8 6 . 4}$ & $\mathbf{1 4 . 3}$ & $\mathbf{3 1 . 1}$ & $\mathbf{2 . 1}$ & $\mathbf{2 . 9}$ & $\mathbf{5 . 5}$ & $\mathbf{3 9 . 3}$ \\
Frankfurt (Oder) & 84.2 & 9.6 & 23.5 & 6.3 & 1 & 9.2 & 48.1 \\
Leipzig & 90.5 & 18.7 & 33.1 & 1.1 & 2.2 & 4.5 & 36.1 \\
Magdeburg & 88.8 & 11.1 & 32.3 & 2 & 1.2 & 7.5 & 43.8 \\
Mecklenburg & 83.9 & 9.4 & 31.1 & 1.2 & 1.7 & 9.5 & 44.8 \\
Merseburg & 85.3 & 24.3 & 19.8 & 1.6 & 1.2 & 8.1 & 42.6 \\
Potsdam I & 85 & 20.1 & 26.7 & 3 & 0.8 & 9 & 38.1 \\
Potsdam II & 81.9 & 20.3 & 26.3 & 5.2 & 1.1 & 10.9 & 33 \\
Thuringia & 85.6 & 16.8 & 22.1 & 4.7 & 1.6 & 4.7 & 43.4 \\
\hline Overall & 85.6 & 18.0 & 26.9 & 3.0 & 1.4 & 7.2 & 40.1 \\
\hline \hline
\end{tabular}

$\overline{\text { Vote shares and turnout by constituencies in the election of the Reichstag on July } 31^{\text {th }}, 1932 . \text { The electoral }}$ district of Dresden-Bautzen mainly coincides with the district of Dresden. Source: Statistisches Reichsamt Germany (1926)

First, policy preferences or beliefs must not have differed before television broadcasting began in the 1950s. Table 3 offers information on voting behavior at the Reichstag election of 1932 for electoral districts located in areas that became part of the GDR after World War II. The constituency "Dresden-Bautzen" is geographically mostly identical to the later GDR district Dresden. The electoral data does not indicate systematic differences between Dresden and other East German constituencies in voter turnout or vote shares of the most prominent parties. Especially, the total vote share of the two leftist parties, the communist party (KPD) and the social democrats (SPD), accounts for $45.4 \%$ in Dresden-Bautzen, which is almost identical to the average of $44.9 \%$ in all East German districts, although the distribution of votes between these two parties differs somewhat.

\footnotetext{
${ }^{15}$ The complete summary statistics are available in Table 15 and 16 in the appendix.
} 
Second, both groups should be comparable with respect to other characteristics which may have an impact on individual beliefs. If, for instance, the economic conditions have been different in regions with and without Western television, beliefs about the relevance of effort may simply reflect different economic opportunities faced by individuals in each region. ${ }^{16}$ Therefore, Table 4 compares the Dresden-district with other parts of the GDR. Indeed Dresden is - compared to the GDR-average - more industrialized, and its inhabitants seem to have a stronger interest in culture as indicated by the higher share of theater visitors.

To take these observable differences between the Dresden-districts and other parts of the GDR into account, the baseline regressions include several district characteristics (such as population density, share of agricultural and industrial employment) and the regional unemployment rate after reunification. Moreover, in section 6 several additional control variables are included which account for alternative explanations for different beliefs. The robustness of the results is further tested by varying the control group since Table 4 indicates that the choice of districts which serve as a comparison group for Dresden may be crucial for the empirical analysis.

A further challenge to my identification is migration since this raises the possibility of self-selection. Spatial mobility in the GDR, however, was very low during the 40 years of its existence. This was mainly a consequence of the central-planned economy with the strong regional specialization on certain industries that hampered the mobility of workers. Beyond that the GDR faced a considerable housing shortage that further limited mobility.

Table 5 presents official statistics on population movements by district for the year 1988 . There were some internal population movements with Berlin attracting people at the costs of most of the other districts. In general, a considerable part of all movements took place within districts. In Dresden-district these movements account for nearly 55 percent. In 1988 the net population outflow by district ranged from 0.52 to 1.54 percent of the total population, with Dresden being located at the lower end of this range.

\footnotetext{
${ }^{16}$ Dresden was an important industrial region already before World War I and this might have given it a better start after reunification. The traditional industries in Dresden (as well as other parts of Saxony, Berlin, and Magdeburg) established before 1945 were more likely to have a comparative advantage than the new "planned industries" which had mainly been established as substitutes for industries located in the FRG (Grundmann, 1997). Then, individuals from Dresden would have had a better starting position after the reunification and might conclude from their relative favorable economic situation that effort pays off.
} 
Table 4: COMPARISON OF GDR-DISTRICTS

\begin{tabular}{|c|c|c|c|c|c|c|c|c|c|c|c|c|}
\hline & (1) & $(2)$ & (1)-(2) & (3) & (1)-(3) & $(4)$ & (1)-(4) & (5) & $(1)-(5)$ & $(6)$ & $(7)$ & $(6)-(7)$ \\
\hline & Dresden & $\begin{array}{c}\text { GDR with } \\
\text { Western television }\end{array}$ & (p-value) & excl. Berlin & (p-value) & Saxony & (p-value) & Eastern GDR & (p-value) & Valley & GDR & (p-value) \\
\hline Population density & 254 & 408.25 & $\begin{array}{l}-154.25 \\
(0.5534)\end{array}$ & 156.82 & $\begin{array}{l}-97.18 \\
(0.0017)\end{array}$ & 285 & $\begin{array}{c}-31 \\
(0.3193)\end{array}$ & 168.67 & $\begin{array}{l}-85.33 \\
(0.3292)\end{array}$ & 146.33 & 408.25 & $\begin{array}{l}-261.92 \\
(0.6226)\end{array}$ \\
\hline $\begin{array}{l}\text { Female population } \\
\text { (\% district pop.) }\end{array}$ & 52.6 & 52.01 & $\begin{array}{c}0.59 \\
(0.0030)\end{array}$ & 51.97 & $\begin{array}{c}-0.63 \\
(0.0037)\end{array}$ & 52.85 & $\begin{array}{c}-0.25 \\
(0.4120)\end{array}$ & 51.84 & $\begin{array}{l}-0.7573 \\
(0.3354)\end{array}$ & 51.6 & 52.01 & $\begin{array}{c}-0.41 \\
(0.3193)\end{array}$ \\
\hline $\begin{array}{l}\text { Working age population } \\
\text { (\% district pop.) }\end{array}$ & 62.9 & 65.03 & $\begin{array}{l}-2.13 \\
(0.0000)\end{array}$ & 64.81 & $\begin{array}{c}1.91 \\
(0.0000)\end{array}$ & 63.75 & $\begin{array}{c}-0.85 \\
(0.3656)\end{array}$ & 64.87 & $\begin{array}{c}1.91 \\
(0.1508)\end{array}$ & 64.63 & 65.03 & $\begin{array}{c}-0.4 \\
(0.6049)\end{array}$ \\
\hline $\begin{array}{l}\text { High educated workers } \\
\text { (\% working pop.) }\end{array}$ & 20.6 & 20.1 & $\begin{array}{c}0.5 \\
(0.6894)\end{array}$ & 18.93 & $\begin{array}{c}1.67 \\
(0.0009)\end{array}$ & 18.85 & $\begin{array}{c}1.75 \\
(0.5177)\end{array}$ & 18.85 & $\begin{array}{l}-1.67 \\
(0.1568)\end{array}$ & 20.17 & 20.1 & $\begin{array}{c}0.07 \\
(0.9796)\end{array}$ \\
\hline $\begin{array}{l}\text { Relative Labor Income } \\
\text { (GDR average } \overline{1} 00 \text { ) }\end{array}$ & 99 & 101.08 & $\begin{array}{l}-2.08 \\
(0.0739)\end{array}$ & 100.91 & $\begin{array}{c}1.91 \\
(0.1249)\end{array}$ & 98.5 & $\begin{array}{c}0.5 \\
(0.7952)\end{array}$ & 103 & $\begin{array}{c}4 \\
(0.4015)\end{array}$ & 98.67 & 101.08 & $\begin{array}{c}-2.41 \\
(0.2928)\end{array}$ \\
\hline $\begin{array}{l}\text { Industrial employment } \\
\text { (\% total empl.) }\end{array}$ & 42.8 & 37.39 & $\begin{array}{c}5.41 \\
(0.0501)\end{array}$ & 38.49 & $\begin{array}{c}-4.31 \\
(0.1039)\end{array}$ & 44 & $\begin{array}{c}-1.2 \\
(0.8187)\end{array}$ & 40.07 & $\begin{array}{l}-2.73 \\
(0.6672)\end{array}$ & 29.27 & 37.39 & $\begin{array}{c}-8.12 \\
(0.1908)\end{array}$ \\
\hline $\begin{array}{l}\text { Agricultural employment } \\
\text { (\% total empl.) }\end{array}$ & 8.1 & 11.19 & $\begin{array}{l}-3.09 \\
(0.0806)\end{array}$ & 12.12 & $\begin{array}{c}4.02 \\
(0.0190)\end{array}$ & 7.15 & $\begin{array}{c}0.95 \\
(0.5604)\end{array}$ & 10.09 & $\begin{array}{c}2.8 \\
(0.4306)\end{array}$ & 16.53 & 11.19 & $\begin{array}{c}5.34 \\
(0.0000)\end{array}$ \\
\hline $\begin{array}{l}\text { Industrial production } \\
\text { (\% GDR ind. prod.) }\end{array}$ & 10.7 & 7.01 & $\begin{array}{c}3.69 \\
(0.0062)\end{array}$ & 7.15 & $\begin{array}{l}-3.56 \\
(0.0135)\end{array}$ & 10.15 & $\begin{array}{c}0.55 \\
(0.8536)\end{array}$ & 8.5 & $\begin{array}{c}-2.2 \\
(0.3886)\end{array}$ & 5.27 & 7.01 & $\begin{array}{c}-1.74 \\
(0.5066)\end{array}$ \\
\hline $\begin{array}{l}\text { Hospital beds } \\
\text { (per 10,000 inhabit.) }\end{array}$ & 95.7 & 99.22 & $\begin{array}{l}-3.52 \\
(0.3879)\end{array}$ & 97.71 & $\begin{array}{c}2.01 \\
(0.6224)\end{array}$ & 105.8 & $\begin{array}{c}-10.1 \\
(0.5842)\end{array}$ & 83.67 & $\begin{array}{l}-12.03 \\
(0.1403)\end{array}$ & 95.97 & 99.22 & $\begin{array}{l}-3.25 \\
(0.6979)\end{array}$ \\
\hline $\begin{array}{l}\text { Theater visitors } \\
\text { (\% district pop.) }\end{array}$ & 0.0019 & 0.0015 & $\begin{array}{c}0.0004 \\
(0.0189)\end{array}$ & 0.0014 & $\begin{array}{l}-0.0007 \\
(0.0015)\end{array}$ & 0.0014 & $\begin{array}{l}0.0005 \\
(0.0340)\end{array}$ & 0.0012 & $\begin{array}{l}-0.0007 \\
(0.0820)\end{array}$ & 0.0018 & 0.0015 & $\begin{array}{c}0.0003 \\
(0.3634)\end{array}$ \\
\hline
\end{tabular}

Neubrandenburg, and Rostock). Sources: GDR Statistical Office, information on labor income and share of working population with university degree from (Kind, 1997). 
Self-selection of individuals into regions with and without Western television may already have occurred at the beginning of television broadcasting in the 1950s. Population movements between 1953 and 1957 seem, however, not to be driven by current or expected future reception of Western television. Dresden, where these popular broadcasts were not available, experienced a net inflow, whereas seven districts faced a net population outflow.

Table 5: Internal And eXternal migration In the GDR 1988/89

\begin{tabular}{|c|c|c|c|c|c|}
\hline \multirow[b]{2}{*}{ District } & \multicolumn{3}{|c|}{ Internal migration } & \multicolumn{2}{|c|}{ Cross-border migration (1989) } \\
\hline & $\begin{array}{c}\text { net outflow } \\
1953-1957(\%)^{*}\end{array}$ & $\begin{array}{c}\% \text { within } \\
\text { districts }\end{array}$ & $\begin{array}{l}\text { net outflow } \\
1988(\%)^{*}\end{array}$ & gross emigration & $\begin{array}{c}\text { emigrants } \\
(\%)^{*}\end{array}$ \\
\hline Berlin & & & & 33683 & 2.62 \\
\hline Cottbus & -1.48 & 49.22 & 0.99 & 13516 & 1.53 \\
\hline Dresden & -0.15 & 54.54 & 0.70 & 46017 & 2.62 \\
\hline Erfurt & 0.73 & 50.85 & 0.66 & 20445 & 1.65 \\
\hline Frankfurt & -3.61 & 36.56 & 1.54 & 10788 & 1.51 \\
\hline Gera & -0.34 & 51.99 & 0.83 & 15632 & 2.11 \\
\hline Halle & 1.19 & 52.14 & -0.93 & 27319 & 1.54 \\
\hline Karl-Marx-Stadt & 3.07 & 61.47 & 0.52 & 40347 & 2.17 \\
\hline Leipzig & -0.31 & 44.82 & 0.97 & 30654 & 2.25 \\
\hline Magdeburg & 0.84 & 52.50 & 0.74 & 14761 & 1.18 \\
\hline Neubrandenburg & 2.70 & 41.34 & 1.33 & 4590 & 0.74 \\
\hline Potsdam & -3.19 & 42.45 & 1.10 & 17026 & 1.52 \\
\hline Rostock & -0.55 & 46.29 & 1.09 & 11279 & 1.23 \\
\hline Schwerin & 1.45 & 46.02 & 1.02 & 6029 & 1.01 \\
\hline Suhl & 0.91 & 43.42 & 0.74 & 4872 & 0.89 \\
\hline$\overline{\text { GDR }}$ & & & & 296958 & 1.64 \\
\hline Average & 0.09 & 48.12 & 0.81 & & \\
\hline
\end{tabular}

* As a share of total district population in the previous year. Source: Information on internal migration based on GDR Statistical Office (various years).

After the Berlin wall had been built in August 1961 approximately 750,000 people emigrated from the GDR until 1989 (Maretzke, 1991). The GDR statistical office provided official data on cross-border migration in 1989 (column 5 and 6 of Table 5). The GDR regime opened the borders to the FRG in November and, thus, gave the citizens the opportunity to emigrate. Already in 1989, within two months after the borders had been opened, around 297,000 people left the GDR. The emigration as a percentage of total district population ranges from 0.74 in Neubrandenburg to 2.62 in Berlin and Dresden. Compared to individuals in other districts, those from Dresden were more likely to leave the GDR. However, this difference is not large.

Although I cannot completely rule out the possibility of self-selection, I address this issue by using longitudinal data. Doing so, I can control for spatial mobility once the treatment 
status of an individual has been identified based on his or her place of residence in June 1990. In principle, my findings could also be driven by some Dresden-specific factor. In section 6 , I discuss and test the relevance of several alternative explanations of the findings. Since the results remain robust, I am confident that my findings can be explained by differential access to Western television.

\section{Results}

Table 6 presents the empirical findings concerning the determinants of the belief that effort pays off during the late 1980s. I employ a probit approach since the dependent variable is binary. As a first test of the robustness of the results to the inclusion of control variables, I gradually add a set of variables capturing individual- and district-level characteristics. I start with a regression of the respondents' belief on the Dresden-dummy (i.e. the treatment indicator), the second specification adds a set of individual-level controls and specification 3 further includes district-level characteristics.

As can be seen, living in a region with access to Western television increases the probability to believe that effort pays off by almost 7 percentage points. A possible interpretation of this finding is that Western television has offered GDR citizens a "window to the Western world" with its values and attitudes through both political reporting and entertainment and thereby has made them share a belief more common in the West.

Apart from Western television exposure, several socioeconomic characteristics have a significant impact on individual beliefs. The probability of stressing the importance of effort for success is, other things equal, lower for male, married, better educated, ${ }^{17}$ and poorer individuals.

Does the effect of differential access to Western television on East Germans' beliefs persist after FRG broadcasts had been available in all parts of the GDR and individuals could also learn about life in West Germany by their own experience? Table 7 displays the results of the probit estimates on the determinants of beliefs between 1994 and 1999. In the first column, the belief that success in life is mainly a matter of luck is regressed on the Dresden-dummy

\footnotetext{
${ }^{17}$ The fact that highly-educated individuals are less inclined to believe that effort pays off for themselves might be a consequence of the communist system itself: income inequality was low in the GDR, implying that a person with an university degree had no substantially higher income than a low educated worker. Hence, the beliefs of highly-educated individuals may simply reflect their personal experience. Another explanation might be that only citizens who agree with socialism were allowed to attend a university.
} 
Table 6: EFForT PAYS OFF, GDR LATE 1980s

\begin{tabular}{|c|c|c|c|}
\hline & $(1)$ & $(2)$ & $(3)$ \\
\hline Dresden & $\begin{array}{c}-0.0664^{* * *} \\
(0.0229)\end{array}$ & $\begin{array}{c}-0.0645^{* * *} \\
(0.0212)\end{array}$ & $\begin{array}{c}-0.0682^{* * *} \\
(0.0201)\end{array}$ \\
\hline Age & & $\begin{array}{l}-0.0103 \\
(0.0172)\end{array}$ & $\begin{array}{l}-0.0108 \\
(0.0182)\end{array}$ \\
\hline $\mathrm{Age}^{2}$ & & $\begin{array}{c}0.0002 \\
(0.0003)\end{array}$ & $\begin{array}{c}0.0002 \\
(0.0003)\end{array}$ \\
\hline Female & & $\begin{array}{c}0.1222^{* * * *} \\
(0.0363)\end{array}$ & $\begin{array}{c}0.1284^{* * *} \\
(0.0357)\end{array}$ \\
\hline Married & & $\begin{array}{l}-0.0503^{*} \\
(0.0260)\end{array}$ & $\begin{array}{l}-0.0428^{*} \\
(0.0252)\end{array}$ \\
\hline Widowed or divorced & & $\begin{array}{l}-0.0475 \\
(0.0415)\end{array}$ & $\begin{array}{l}-0.0371 \\
(0.0432)\end{array}$ \\
\hline Children & & $\begin{array}{c}0.0309 \\
(0.0360)\end{array}$ & $\begin{array}{c}0.0306 \\
(0.0360)\end{array}$ \\
\hline Net income & & $\begin{array}{c}0.0088^{* *} \\
(0.0039)\end{array}$ & $\begin{array}{c}0.0111^{* * *} \\
(0.0033)\end{array}$ \\
\hline Intermediate education & & $\begin{array}{c}-0.0735^{*} \\
(0.0427)\end{array}$ & $\begin{array}{c}-0.0709^{*} \\
(0.0398)\end{array}$ \\
\hline High education & & $\begin{array}{l}-0.0423 \\
(0.0394)\end{array}$ & $\begin{array}{l}-0.0322 \\
(0.0403)\end{array}$ \\
\hline University degree & & $\begin{array}{c}-0.1534^{* * *} \\
(0.0450)\end{array}$ & $\begin{array}{c}-0.1585^{* * *} \\
(0.0456)\end{array}$ \\
\hline Population density & & & $\begin{array}{l}-0.0001 \\
(0.0001)\end{array}$ \\
\hline Industrial employment & & & $\begin{array}{l}-0.0059 \\
(0.0078)\end{array}$ \\
\hline Agricultural employment & & & $\begin{array}{l}-0.0049 \\
(0.0133)\end{array}$ \\
\hline Pseudo R2 & 0.0023 & 0.0190 & 0.0224 \\
\hline Observations & 3381 & 2517 & 2517 \\
\hline \multicolumn{4}{|c|}{$\begin{array}{l}\text { Notes: Probit regressions (marginal effects are shown). Omitted } \\
\text { categories are male, never married, and finished } 8^{t h} \text { grade (or } \\
\text { less) in school. Robust standard errors in parentheses, clustered } \\
\text { at district level. } * * * / * * / * \text { denotes significance at the } 1 \% / 5 \% / 10 \% \\
\text { level. }\end{array}$} \\
\hline
\end{tabular}

and year fixed effects. The following specifications successively add a set of individual-level controls (specification 2), the regional unemployment rate (specification 3) and current state of residence fixed effect (specification 4).

The findings suggest that the exposure to FRG television had a persistent effect on East Germans' beliefs: persons who had access to Western television were less likely to believe that luck determines opportunities in life than individuals from parts of the GDR without Western television. This is the case, although I control for the current economic factors (e.g. net household income, occupation, and employment status) and regional unemployment. The effect of television on individual beliefs is also sizeable as the marginal effect of the Dresden- 
Table 7: SuCCESS IN LIFE IS MAINLY A MATTER OF LUCK, FRG 1994-1999

\begin{tabular}{|c|c|c|c|c|}
\hline & $(1)$ & $\overline{(2)}$ & $(3)$ & $(4)$ \\
\hline Dresden & $\begin{array}{c}0.0321^{* *} \\
(0.0153)\end{array}$ & $\begin{array}{c}0.0402^{* * *} \\
(0.0112)\end{array}$ & $\begin{array}{c}0.0447^{* * *} \\
(0.0121)\end{array}$ & $\begin{array}{c}0.0481^{* * *} \\
(0.0144)\end{array}$ \\
\hline Age & & $\begin{array}{c}-0.0181^{* * *} \\
(0.0061)\end{array}$ & $\begin{array}{c}-0.0178^{* * *} \\
(0.0061)\end{array}$ & $\begin{array}{c}-0.0180^{* * *} \\
(0.0064)\end{array}$ \\
\hline $\mathrm{Age}^{2}$ & & $\begin{array}{c}0.0004^{* * *} \\
(0.0001)\end{array}$ & $\begin{array}{c}0.0004^{* * *} * \\
(0.0001)\end{array}$ & $\begin{array}{c}0.0004 * * * \\
(0.0001)\end{array}$ \\
\hline $\mathrm{Age}^{3}$ & & $\begin{array}{c}-0.0000^{* * *} \\
(0.0000)\end{array}$ & $\begin{array}{c}-0.0000^{* * *} \\
(0.0000)\end{array}$ & $\begin{array}{c}-0.0000^{* * *} * \\
(0.0000)\end{array}$ \\
\hline Female & & $\begin{array}{c}0.0405^{* * *} \\
(0.0110)\end{array}$ & $\begin{array}{c}0.0405^{* * *} \\
(0.0111)\end{array}$ & $\begin{array}{c}0.0400 * * * \\
(0.0106)\end{array}$ \\
\hline Father's education & & $\begin{array}{c}-0.0204^{* *} \\
(0.0087)\end{array}$ & $\begin{array}{c}-0.0196^{* *} \\
(0.0089)\end{array}$ & $\begin{array}{c}-0.0185^{* *} \\
(0.0078)\end{array}$ \\
\hline Married & & $\begin{array}{c}0.0214 \\
(0.0188)\end{array}$ & $\begin{array}{c}0.0204 \\
(0.0192)\end{array}$ & $\begin{array}{c}0.0178 \\
(0.0205)\end{array}$ \\
\hline Married but separated & & $\begin{array}{c}0.0620 \\
(0.0436)\end{array}$ & $\begin{array}{c}0.0607 \\
(0.0450)\end{array}$ & $\begin{array}{c}0.0658 \\
(0.0440)\end{array}$ \\
\hline Widowed or divorced & & $\begin{array}{c}0.0366 \\
(0.0351)\end{array}$ & $\begin{array}{c}0.0358 \\
(0.0351)\end{array}$ & $\begin{array}{c}0.0343 \\
(0.0358)\end{array}$ \\
\hline Not employed & & $\begin{array}{c}0.0164 \\
(0.0201)\end{array}$ & $\begin{array}{c}0.0172 \\
(0.0201)\end{array}$ & $\begin{array}{c}0.0142 \\
(0.0201)\end{array}$ \\
\hline Retired & & $\begin{array}{c}0.0117 \\
(0.0196)\end{array}$ & $\begin{array}{c}0.0116 \\
(0.0196)\end{array}$ & $\begin{array}{c}0.0119 \\
(0.0199)\end{array}$ \\
\hline Unemployed & & $\begin{array}{c}0.0263 * \\
(0.0135)\end{array}$ & $\begin{array}{l}0.0256^{*} \\
(0.0137)\end{array}$ & $\begin{array}{l}0.0252^{*} \\
(0.0139)\end{array}$ \\
\hline Self employed & & $\begin{array}{l}-0.0027 \\
(0.0181)\end{array}$ & $\begin{array}{l}-0.0020 \\
(0.0181)\end{array}$ & $\begin{array}{l}-0.0041 \\
(0.0178)\end{array}$ \\
\hline Civil servant & & $\begin{array}{c}0.0806^{* *} \\
(0.0359)\end{array}$ & $\begin{array}{c}0.0806^{* *} \\
(0.0366)\end{array}$ & $\begin{array}{c}0.0863^{* *} \\
(0.0346)\end{array}$ \\
\hline White collar & & $\begin{array}{c}-0.0212^{* * *} \\
(0.0053)\end{array}$ & $\begin{array}{c}-0.0217^{* * *} \\
(0.0051)\end{array}$ & $\begin{array}{c}-0.0233^{* * * *} \\
(0.0052)\end{array}$ \\
\hline University degree & & $\begin{array}{c}-0.0814^{* * *} \\
(0.0161)\end{array}$ & $\begin{array}{c}-0.0809 * * * \\
(0.0159)\end{array}$ & $\begin{array}{c}-0.0778^{* * *} \\
(0.0153)\end{array}$ \\
\hline High education & & $\begin{array}{c}-0.1110^{* * *} \\
(0.0227)\end{array}$ & $\begin{array}{c}-0.1103^{* * *} \\
(0.0234)\end{array}$ & $\begin{array}{c}-0.1075^{* * *} \\
(0.0238)\end{array}$ \\
\hline Intermediate education & & $\begin{array}{c}-0.0384^{* *} \\
(0.0166)\end{array}$ & $\begin{array}{c}-0.0379^{* *} \\
(0.0166)\end{array}$ & $\begin{array}{c}-0.0379 * * \\
(0.0170)\end{array}$ \\
\hline No. persons in household & & $\begin{array}{c}0.0252^{* * *} \\
(0.0097)\end{array}$ & $\begin{array}{c}0.0245^{* *} \\
(0.0100)\end{array}$ & $\begin{array}{c}0.0217^{* *} \\
(0.0086)\end{array}$ \\
\hline No. children in household & & $\begin{array}{c}-0.0276^{* * *} \\
(0.0103)\end{array}$ & $\begin{array}{c}-0.0269^{* *} \\
(0.0108)\end{array}$ & $\begin{array}{c}-0.0247^{* *} \\
(0.0104)\end{array}$ \\
\hline Log. household income & & $\begin{array}{c}-0.0822^{* * *} \\
(0.0141)\end{array}$ & $\begin{array}{c}-0.0810^{* * *} \\
(0.0146)\end{array}$ & $\begin{array}{c}-0.0760^{* * *} \\
(0.0156)\end{array}$ \\
\hline Currently living in West Germany & & $\begin{array}{l}-0.0142 \\
(0.0295)\end{array}$ & $\begin{array}{c}0.0425 \\
(0.0479)\end{array}$ & $\begin{array}{c}-0.0151^{* *} \\
(0.0076)\end{array}$ \\
\hline Unemployment experience & & $\begin{array}{c}0.0082^{* *} \\
(0.0033)\end{array}$ & $\begin{array}{c}0.0083^{* *} \\
(0.0032)\end{array}$ & $\begin{array}{c}0.0078^{* *} \\
(0.0035)\end{array}$ \\
\hline Unemployment rate (state level) & & & $\begin{array}{c}0.0081 \\
(0.0063)\end{array}$ & $\begin{array}{c}0.0128^{* * *} * \\
(0.0035)\end{array}$ \\
\hline Year FE & YES & YES & YES & YES \\
\hline State FE & NO & NO & NO & YES \\
\hline Pseudo R2 & 0.0094 & 0.0671 & 0.0678 & 0.0732 \\
\hline Observations & 12168 & 10356 & 10356 & 10352 \\
\hline
\end{tabular}

Notes: Probit regressions (marginal effects are shown). Omitted categories are male, never married, being still in education, and less than 9 years of schooling. Robust standard errors in parentheses, clustered at Nuts2-level. ***/**/* denotes significance at the $1 \% / 5 \% / 10 \%$ level.

dummy ranges from 3.2 to 4.8 percentage points. Thus, the impact of FRG television is 1.5 to 2 times the effect of being currently unemployed.

Several further explanatory variables affect individual beliefs. The respondent's age has a significant but non-linear impact. The probability of believing that luck is a major de- 
terminant of success is higher for women, unemployed respondents, blue collar workers, and civil servants. Furthermore, the perceived relevance of luck decreases with both the respondent's own and his or her father's level of education, ${ }^{18}$ the household income, the number of children living in the same household and increases with the household size as well as former unemployment experience. Finally, living in states with higher unemployment as well as in West Germany increases the perceived importance of luck (at least if other state characteristics are captured by current state of residence fixed effects).

The regression results presented in Table 8 provide further insights into how the impact of differential access to West German television on East Germans' belief that success in life is mainly a matter of luck developed during the 1990s. ${ }^{19}$

Regression (1) is equal to specification 4 in Table 7 but reports the year fixed effects explicitly. Overall, East Germans were less likely to believe that success in life is a matter of luck between 1994 and 1996 than they were in 1999. The interaction of the Dresden-dummy and the year dummies (specification 2) reveals that individuals experienced a different development in beliefs depending on their opportunity to watch Western television in the GDR. While the probability to state that luck matters for success is decreasing over time for individuals from the former district of Dresden, those from other parts of the GDR became more inclined to stress the relevance of luck during 1990s. This is also supported by a differential time trend (comp. specification 3 and 4). Thus, there has been a convergence in the perceived importance of luck for success in life between individuals with and without access to West German broadcasts during German separation.

Furthermore, I test the relevance of age or cohort effects for the convergence of beliefs. The results of specification 5 do not point at any differential impact of age on the belief that luck matters. The analysis of five different birth cohorts, however, reveals significant differences between Dresden and the rest of the GDR. Compared to the oldest group of individuals (i.e. those born before 1920), younger cohorts in Dresden are more inclined to believe that success in life is mainly driven by luck. For individuals from other parts of the GDR no such significant difference between the cohort groups exists.

\footnotetext{
${ }^{18}$ The results do not change if instead of the father's the mother's level of education is included.

${ }^{19}$ The findings shown in Table 8 are based on a linear probability model since marginal effects of interaction terms as calculated in nonlinear models (such as Probit) are likely to be inconsistent (Ai and Norton, 2003). By estimating a linear probability model, it is possible to interpret the significance and direction of the interaction effect.
} 
Table 8: SucCess in Life is MAinly a MATter of LUCK, FRG 1994-1999 - RegresSIONS WITH INTERACTION EFFECTS

\begin{tabular}{|c|c|c|c|c|c|c|c|}
\hline & \multicolumn{4}{|c|}{ Convergence or Divergence in beliefs } & \multicolumn{2}{|c|}{ Age vs. Cohort effects } & \multirow{2}{*}{$\begin{array}{c}\text { West Germany } \\
(7)\end{array}$} \\
\hline & $(1)$ & $(2)$ & $(3)$ & $(4)$ & & $(6)$ & \\
\hline Dresden & $\begin{array}{c}0.0501^{* * *} \\
(0.0143)\end{array}$ & $\begin{array}{c}0.0202 \\
(0.0178)\end{array}$ & $\begin{array}{c}0.0502^{* * *} \\
(0.0143)\end{array}$ & $\begin{array}{c}0.1108 * * * \\
(0.0205)\end{array}$ & $\begin{array}{c}0.0316 \\
(0.0266)\end{array}$ & $\begin{array}{l}-0.0203 \\
(0.0230)\end{array}$ & $\begin{array}{c}0.0470^{* * *} \\
(0.0134)\end{array}$ \\
\hline 1994 & $\begin{array}{c}-0.0466^{* * *} \\
(0.0136)\end{array}$ & $\begin{array}{c}-0.0488^{* * * *} \\
(0.0150)\end{array}$ & & & & & \\
\hline 1995 & $\begin{array}{c}-0.0415^{* * *} \\
(0.0137)\end{array}$ & $\begin{array}{c}-0.0418^{* * *} \\
(0.0128)\end{array}$ & & & & & \\
\hline 1996 & $\begin{array}{c}-0.0768^{* * *} \\
(0.0119)\end{array}$ & $\begin{array}{c}-0.0796^{* * *} \\
(0.0117)\end{array}$ & & & & & \\
\hline 1994 x Dresden & & $\begin{array}{c}0.0380^{* * *} \\
(0.0130)\end{array}$ & & & & & \\
\hline 1995 x Dresden & & $\begin{array}{c}0.0352^{* * *} \\
(0.0097)\end{array}$ & & & & & \\
\hline 1996 x Dresden & & $\begin{array}{c}0.0430^{* *} \\
(0.0163)\end{array}$ & & & & & \\
\hline Time trend & & & $\begin{array}{c}0.0112^{* * *} \\
(0.0026)\end{array}$ & $\begin{array}{c}0.0122^{* * *} \\
(0.0026)\end{array}$ & & & \\
\hline Time trend $\mathrm{x}$ Dresden & & & & $\begin{array}{c}-0.0088^{* * *} \\
(0.0022)\end{array}$ & & & \\
\hline Age & & & & & $\begin{array}{c}0.0010 \\
(0.0009)\end{array}$ & & \\
\hline Age x Dresden & & & & & $\begin{array}{l}0.0005 \\
(0.0005)\end{array}$ & & \\
\hline Born $1920-1945$ & & & & & & $\begin{array}{c}0.0185 \\
(0.0325)\end{array}$ & \\
\hline Born 1946 - 1960 & & & & & & $\begin{array}{c}0.0008 \\
(0.0385)\end{array}$ & \\
\hline Born 1961 - 1975 & & & & & & $\begin{array}{l}-0.0160 \\
(0.0541)\end{array}$ & \\
\hline Born 1976 - 1990 & & & & & & $\begin{array}{c}0.0012 \\
(0.0642)\end{array}$ & \\
\hline Born 1920 - 1945 x Dresden & & & & & & $\begin{array}{c}0.0888^{* * *} \\
(0.0386)\end{array}$ & \\
\hline Born 1946 - 1960 x Dresden & & & & & & $\begin{array}{c}0.0722^{* *} \\
(0.0325)\end{array}$ & \\
\hline Born 1961 - 1975 x Dresden & & & & & & $\begin{array}{c}0.0536^{* * *} \\
(0.0336)\end{array}$ & \\
\hline Born 1976 - 1990 x Dresden & & & & & & $\begin{array}{c}0.0847 * * * \\
(0.0433)\end{array}$ & \\
\hline West Germany & & & & & & & $\begin{array}{c}-0.0188^{* *} \\
(0.0092)\end{array}$ \\
\hline West Germany x Dresden & & & & & & & $\begin{array}{c}0.0536 \\
(0.0946)\end{array}$ \\
\hline Year FE & & & & & YES & YES & YES \\
\hline Observations & 10356 & 10356 & 10356 & 10356 & 10356 & 10356 & 10356 \\
\hline R2 & 0.0716 & 0.0718 & 0.0690 & 0.0692 & 0.0708 & 0.0716 & 0.0717 \\
\hline
\end{tabular}

Notes: Linear probability model estimated based on specification (4) in Table 7. Robust standard errors in parentheses, clustered at Nuts2-level. $* * * / * * / *$ denotes significance at the $1 \% / 5 \% / 10 \%$ level. 
Finally, recent life experience might not have a similar impact on individuals with differential access to Western television already before reunification. Specification 7 indeed indicates that moving to West Germany has lowered the probability to believe that luck matters for individuals who are originally from regions with access to Western television but has no significant impact on those from Dresden.

Table 9: SucCess in LifE IS MAINLY A MATTER OF LUCK - Time TREND InTERACTED With DRESDEN (BALANCED PANEL)

\begin{tabular}{lccc}
\hline \hline & $(1)$ & $(2)$ & $(3)$ \\
\hline \multirow{2}{*}{ Dresden } & $0.0824^{* * *}$ & $0.0862^{* * *}$ & $0.0899^{* * *}$ \\
Time trend & $(0.0262)$ & $(0.0204)$ & $(0.0224)$ \\
& $0.0207^{* * *}$ & $0.0144^{* * *}$ & $0.0145^{* * *}$ \\
Time trend x Dresden & $(0.0033)$ & $(0.0032)$ & $(0.0029)$ \\
& $-0.0059^{*}$ & $-0.0059^{* *}$ & $-0.0066^{* * *}$ \\
State FE & $(0.0031)$ & $(0.0023)$ & $(0.0023)$ \\
Observations & NO & NO & YES \\
R2 & 9119 & 9119 & 9119 \\
\hline \hline
\end{tabular}

Notes: Based on specifications 2 to 4 Table 7 but restricted to individuals who answered the question on the relevance of luck for success in all years (balanced panel). Robust standard errors in parentheses, clustered at Nuts2-level. ***/**/* denotes significance at the $1 \% / 5 \% / 10 \%$ level.

Table 9 further presents how changes in the cohort composition versus actual changes in respondents' beliefs contribute to the convergence between the two groups. The analysis is based on a balanced panel data set including only individuals who answered all questions between 1994 and 1999. By comparing the differential time trend for this sample with the unbalanced sample used for specification 4 in Table 8, I can calculate the share of the convergence that is driven by a change in cohort composition (i.e. a dropping out of older cohorts) versus the part that is driven by actual changes in beliefs over time. The coefficient of the interaction variable "Time trend x Dresden" is approximately 25 percent smaller for the balanced panel indicating that around 75 percent of the convergence is driven by actual changes in beliefs.

\section{Robustness and some further results}

The empirical findings suggest that East Germans with access to Western television were more inclined to share beliefs more common in the West both before reunification and several 
years afterwards. Dresden seems to be on average comparable to other GDR-districts (see Table 3 and 4). Still, a major concern might be that factors others than television reception cause the differences in beliefs. In the following, I test the robustness of the results by varying the group of districts Dresden is compared to (control group) and include variables which account for alternative explanations.

\subsection{Varying the control group}

In Table 10 the robustness of the results is tested using different groups of districts as a comparison group for Dresden. First, I exclude observations from East Berlin from the sample. The district of Berlin is not fully comparable to other districts due to its position as the capital of the GDR and the fact that the former city of Berlin had been separated by the allied forces. Second, the analysis will be restricted to Saxon districts (Dresden, Leipzig and Karl-Marx-Stadt). These districts share a common history as parts of the Kingdom of Saxony and, therefore, most likely also a common culture and values. Moreover, they are also highly comparable with respect to other characteristics (see Table 4). Furthermore, the observable differences could also be explained by the geographical location of the Dresdendistrict in the Eastern part of the GDR. It could also be the case that after the fall of the Berlin wall higher costs of travelling to West Germany due to the larger distance deters the population in the Eastern part from learning about the West by own experience. If that explains the different beliefs, then the same should apply to all regions located in the East of the GDR. Thus, I restrict the analysis to these regions. For the analysis based on the SOEP also data for the outermost Northeast of the GDR which had only partial access to these broadcasts is available. Hence, the treatment group is extended to both regions without Western television reception (i.e., Dresden and the regional planning unit Greifswald-Stralsund).

The results indicate that the treatment effect remains widely unchanged if East Berlin is excluded or only Saxon districts are analyzed.

If the control is restricted to regions in the East of the GDR, the treatment effect becomes smaller. Furthermore, the treatment effect loses its significance if Greifswald is included as the second part of the GDR with only partial access to Western television. Although this may be an indication that the results are driven by (unobservable) Dresden-specific charac- 
Table 10: Different Group OF Districts

\begin{tabular}{|c|c|c|c|c|c|c|}
\hline & \multicolumn{2}{|c|}{$\begin{array}{c}\text { Effort pays off } \\
\text { GDR, late } 1980 \mathrm{~s}\end{array}$} & \multicolumn{4}{|c|}{$\begin{array}{c}\text { Success in life is mainly a matter of luck } \\
\text { FRG 1994-99 }\end{array}$} \\
\hline & $(1)$ & $(2)$ & $(3)$ & $(4)$ & $(5)$ & $(6)$ \\
\hline & \multicolumn{6}{|c|}{ Baseline } \\
\hline Dresden & $\begin{array}{l}-0.0664^{* * *} \\
(0.0229)\end{array}$ & $\begin{array}{c}-0.0645^{* * *} \\
(0.0212)\end{array}$ & $\begin{array}{c}0.0321^{* *} \\
(0.0153)\end{array}$ & $\begin{array}{c}0.0402^{* * *} \\
(0.0112)\end{array}$ & $\begin{array}{c}0.0447^{* * *} \\
(0.0121)\end{array}$ & $\begin{array}{c}0.0481^{* * *} \\
(0.0144)\end{array}$ \\
\hline Pseudo R2 & 0.0023 & 0.0190 & 0.0094 & 0.0671 & 0.0678 & 0.0732 \\
\hline Observations & 3382 & 2517 & 12168 & 10356 & 10356 & 10352 \\
\hline & \multicolumn{6}{|c|}{ Control group } \\
\hline GDR without & $-0.0783^{* * *}$ & $-0.0759^{* * *}$ & $0.0256^{*}$ & $0.0390 * * *$ & $0.0434^{* * *}$ & $0.0503^{* * *}$ \\
\hline Berlin & $(0.0241)$ & $(0.0215)$ & $(0.0147)$ & $(0.0117)$ & $(0.0132)$ & $(0.0145)$ \\
\hline Pseudo R2 & 0.0035 & 0.0185 & 0.0095 & 0.0684 & 0.0687 & 0.0742 \\
\hline Observations & 2990 & 2258 & 11279 & 9619 & 9619 & 9615 \\
\hline Saxony & $\begin{array}{l}-0.0859 * * * \\
\quad(0.0023)\end{array}$ & $\begin{array}{l}-0.0814^{* * *} \\
\quad(0.0119)\end{array}$ & $\begin{array}{c}0.0298 \\
(0.0203)\end{array}$ & $\begin{array}{c}0.0483^{* * *} \\
(0.0150)\end{array}$ & $\begin{array}{c}0.0480^{* * *} \\
(0.0146)\end{array}$ & $\begin{array}{c}0.0477^{* * *} \\
(0.0146)\end{array}$ \\
\hline Pseudo R2 & 0.0056 & 0.0232 & 0.0088 & 0.0796 & 0.0845 & 0.0878 \\
\hline Observations & 1596 & 1218 & 4115 & 3532 & 3532 & 3522 \\
\hline $\begin{array}{l}\text { Eastern part } \\
\text { of the GDR }\end{array}$ & - & - & $\begin{array}{c}0.0225 \\
(0.0177)\end{array}$ & $\begin{array}{c}0.0435^{* * *} \\
(0.0127)\end{array}$ & $\begin{array}{c}0.0448^{* * *} \\
(0.0133)\end{array}$ & $\begin{array}{c}0.0277^{* * *} \\
(0.0072)\end{array}$ \\
\hline Pseudo R2 & & & 0.0095 & 0.0694 & 0.0696 & 0.0778 \\
\hline \multirow[t]{2}{*}{ Observations } & & & 4068 & 3424 & 3424 & 3414 \\
\hline & \multicolumn{6}{|c|}{ Treatment group } \\
\hline Dresden \& & & & -0.0153 & 0.0004 & 0.0005 & $0.0423^{* * *}$ \\
\hline Greifswald & - & - & $(0.0293)$ & $(0.0314)$ & $(0.0325)$ & $(0.0160)$ \\
\hline Pseudo R2 & & & 0.0095 & 0.0663 & 0.0663 & 0.0729 \\
\hline Observations & & & 10963 & 9317 & 9317 & 9317 \\
\hline
\end{tabular}

Notes: Probit regressions (marginal effects are shown). The results shown in column 1 and 2 are based on the respective specifications in Table 6 , while columns 3 to 6 are based on Table 7 . For further information on included controls see Table 6 and 7 . Robust standard errors in parentheses, clustered at Nuts2-level. $* * * / * * / *$ denotes significance at the $1 \% / 5 \% / 10 \%$ level.

teristics, the partial insignificance does not necessarily imply that Western television has no effect. The area in the Northeast without West German television reception did not coincide perfectly with "Greifswald-Stralsund" (as it was the case with the district of Dresden in the Southeast). ${ }^{20}$ Consequently, the smaller and less significant treatment effect may reflect downward biased estimates as individuals might be assigned to the treatment group who actually had access to Western television. Furthermore, Dresden and Greifswald-Stralsund differ with respect to other characteristics (e.g. Greifswald-Stralsund is more rural). This heterogeneity might have contributed to the loss of significance since the treatment effect

\footnotetext{
${ }^{20}$ This is also indicated by a survey conducted by the central institute for youth research in 1981 . While 68.8 percent of the respondents living in the district of Dresden stated that they did not watch Western television at all, the share in the districts Rostock and Neubrandenburg was only 27 percent.
} 
gets highly significant if state fixed effects controlling for such heterogeneity are included.

\subsection{Alternative explanations for structural differences between Dresden and other parts of the GDR}

Now, I extend the baseline analysis by including additional district level characteristics which account for alternative explanations for the differences in beliefs. The GDR was a planned economy with a considerable amount of regional specialization on certain sectors and industries which affected the composition of the population (e.g. industrial vs. agricultural workers). To capture these differences several variables are added to the baseline regressions of the belief that effort pays off during the late 1980s (see Table 11). The relevance of industrial production in each district (i.e. district's share of gross industrial production of the GDR) is included in column (1). Further controls are the share of working age population (as a percentage of total district population) in column (2) and the level of education of the district's working population (share of workers with an university degree) in column (3). While the share of industrial production has no significant effect on the respondents' beliefs, a higher share of population in their working age and better educated workers increase the probability to believe that effort pays off.

Furthermore, the geographical location of a district may be related to its inhabitants' attitudes. Hence, I include both a variable indicating whether a district has a common border with the FRG and the distance between the district capital and Berlin (in kilometers). The results, however, do not indicate a significant relationship.

Finally, Dresden was famous for its arts and culture. Thus, the population had perhaps been more interested in culture, arts, and literature. More generally, if (traditionally educated) middle-class intellectuals entertain different beliefs than the rest of the population this could also explain the main findings of this paper. Therefore, I include both dummyvariables indicating whether the respondent had lately been to a theater, cinema, or museum (specifications 6 to 8 ) and the number of theater visitors in each district (weighted by the total district population). The individual interest in arts and culture affects beliefs at least partly: Individuals who visited cinema and museums are more likely to belief that effort pays off. Moreover, individuals in districts where a higher share of the population visits theaters are less inclined to believe that effort pays off. 
An overall important finding is that the inclusion of these further control variables does not change the results in substance with the treatment indicator remaining robust and significant.

The identification of the Western television effect during the 1990s does not only depend on the absence of structural differences before reunification but also on the assumption that both regions were not hit by (systematically) different shocks afterwards. Otherwise, the observable differences between individuals from Dresden and those from other parts of the GDR could also be a consequence of differences in the economic or social conditions.

To address these concerns, I add several regional characteristics to my baseline specification using data from the SOEP (see specification 4 in Table 7). Table 12 displays the results. Due to data constraints, the specifications 2 to 6 are only based on observations for the years 1996 and 1999. To enhance the comparability of the results and to distinguish between the impact of different samples and of additional controls, column 1 shows the results of the baseline regression based on observations from 1996 and 1999.

After reunification, wide parts of East Germany faced considerable problems as most parts of the GDR economy were not capable of competing with the West. Since unemployment increased during the 1990s, some East German regions experienced a considerable population loss and demographic problems. To capture related economic and demographic differences, I add each regional planning unit's population density (specification 2), share of inhabitants older than 65 (specification 3), unemployment rate (specification 4), average monthly labor income of industrial workers (specification 5), and GDP per capita (specification 6). The results indicate that only the regional unemployment rate has a significant effect on the respondents likelihood to believe that success is mainly a consequence of luck. More important, the coefficients of the Dresden-dummy remain highly significant and robust. 
Table 11: EfFort PAYs off (GDR, LATE 1980s) - AdDitional CONTROL VARiABles

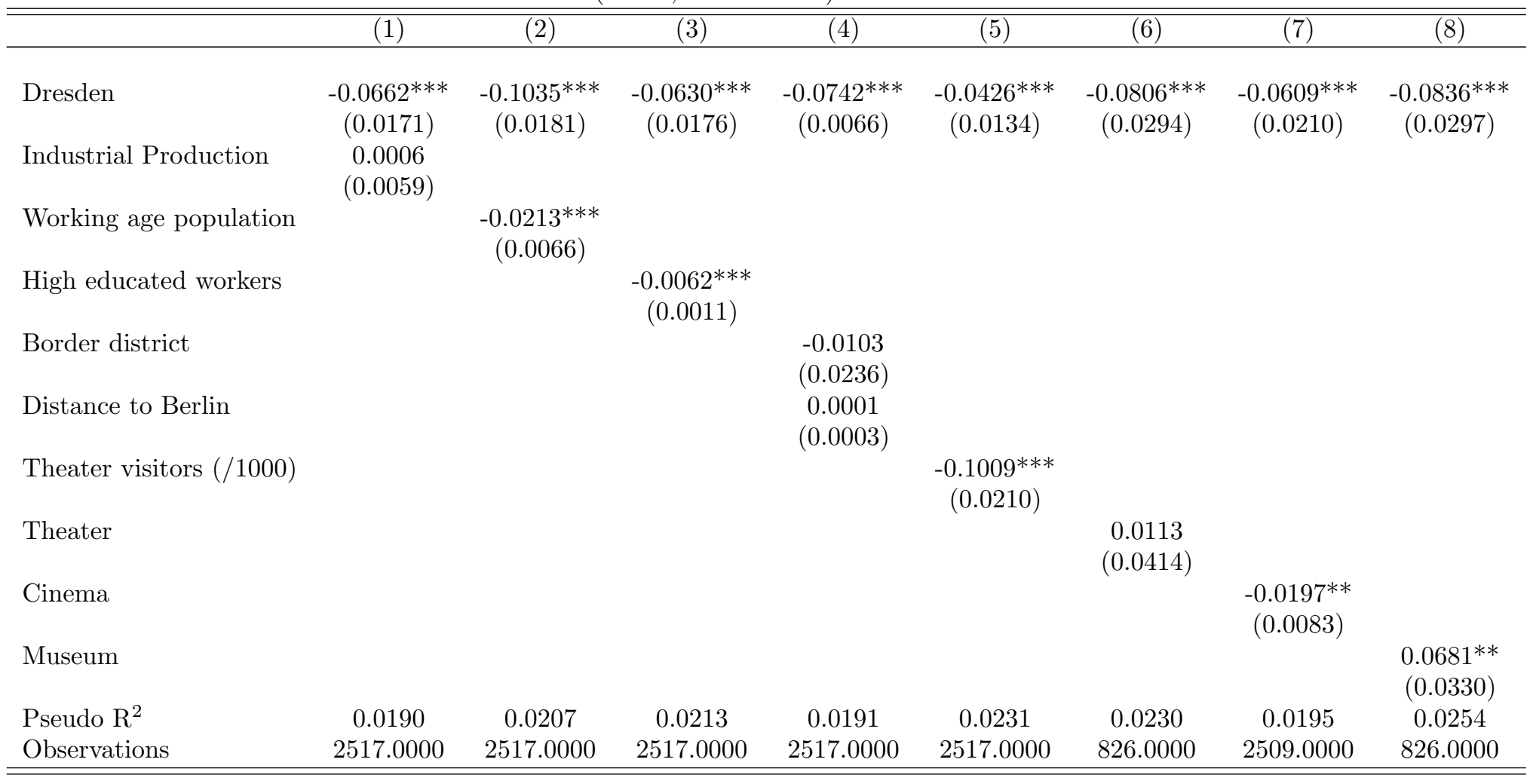

Notes: Probit regressions (marginal effects are shown). Based on the specification presented in the second column of Table 6 . For further information on included controls see Table 6 . Robust standard errors in parentheses, clustered at district level. $* * * / * * / *$ denotes significance at the $1 \% / 5 \% / 10 \%$ level. 
Table 12: LuCK MATters FOR SuCCESS (FRG 1994-99) - AdDitional CONTRol VARIABLES

\begin{tabular}{|c|c|c|c|c|c|c|c|c|}
\hline & (1) & $(2)$ & $(3)$ & (4) & $(5)$ & $(6)$ & $(7)$ & $(8)$ \\
\hline Dresden & $\begin{array}{c}0.0358^{* * *} \\
(0.0118)\end{array}$ & $\begin{array}{c}0.0393^{* * *} \\
(0.0137)\end{array}$ & $\begin{array}{c}0.0367^{* * *} \\
(0.0109)\end{array}$ & $\begin{array}{c}0.0312^{* * *} \\
(0.0110)\end{array}$ & $\begin{array}{c}0.0357^{* * *} \\
(0.0115)\end{array}$ & $\begin{array}{c}0.0348^{* * *} \\
(0.0108)\end{array}$ & $\begin{array}{c}0.0678^{* * *} \\
(0.0161)\end{array}$ & $\begin{array}{c}0.0490^{* * *} \\
(0.0119)\end{array}$ \\
\hline Population density & & $\begin{array}{c}0.0001 \\
(0.0001)\end{array}$ & & & & & & \\
\hline Inhabitants older than 65 & & & $\begin{array}{c}0.0010 \\
(0.0063)\end{array}$ & & & & & \\
\hline Unemployment rate (regional planning unit) & & & & $\begin{array}{c}0.0111^{* * *} \\
(0.0031)\end{array}$ & & & & \\
\hline Average industrial wage & & & & & $\begin{array}{c}0.0000 \\
(0.0000)\end{array}$ & & & \\
\hline GDP per capita & & & & & & $\begin{array}{c}-0.0027 \\
(0.0027)\end{array}$ & & \\
\hline Mother: Catholic & & & & & & & $\begin{array}{c}0.0710^{* *} \\
(0.0303)\end{array}$ & \\
\hline Mother: Protestant & & & & & & & $\begin{array}{c}0.0510^{* * *} \\
(0.0198)\end{array}$ & \\
\hline Mother: Other & & & & & & & $\begin{array}{c}0.0870^{* *} \\
(0.0402)\end{array}$ & \\
\hline Respondent (1990): Catholic & & & & & & & & $\begin{array}{c}-0.0065 \\
(0.0274)\end{array}$ \\
\hline Respondent (1990): Protestant & & & & & & & & $\begin{array}{l}0.0324^{*} \\
(0.0178)\end{array}$ \\
\hline Respondent (1990): Other & & & & & & & & $\begin{array}{c}-0.0702^{*} \\
(0.0360)\end{array}$ \\
\hline Pseudo R2 & 0.0787 & 0.0788 & 0.0787 & 0.0796 & 0.0787 & 0.0787 & 0.0631 & 0.0806 \\
\hline Observations & 5394 & 5394 & 5394 & 5394 & 5394 & 5394 & 2274 & 9212 \\
\hline
\end{tabular}

Notes: Probit regressions (marginal effects are shown). Based on the specification presented in the second column of Table 7 . For further information on included controls see Table 7 . Omitted category in the specifications (8) and (9) is no religion. Robust standard errors in parentheses, clustered at district level. $* * * / * * / *$ denotes significance at the $1 \% / 5 \% / 10 \%$ level. 
Another concern is related to cultural or religious differences between the two groups. Thus, I include the respondent's own religious denomination in 1990 and his or her mother's religion to proxy cultural effects. ${ }^{21}$ The findings suggest a significant impact of religion on the belief regarding the role of luck for success: Individuals with a religious mother (independent of her denomination) are more inclined to believe that luck matters. The results on the respondent's own religion in 1990 show that protestants (and those belonging to other religious communities) tend to be more (less) likely to stress the relevance of luck than those without on religious denomination. The Dresden-dummy again remains robust.

\subsection{Some additional insights into the role of Western television}

The main objective of East German television was the indoctrination of the audience to alter their attitudes toward the GDR and socialism. Kern and Hainmueller (2009) analyze - based on GDR survey data - how access to West German television has affected attitudes toward the GDR in the late 1980s. They find that Western television contributed to a more positive assessment of different aspects of life in the GDR. Their basic explanation for this is that Western television made life in the GDR more bearable, which increased general satisfaction and made East Germans less critical toward the GDR regime and realities of socialism. This is in line with my argument that West German television affected East Germans' beliefs mainly by presenting different world views and values in its entertainment programs. Insofar, Kern and Hainmüller's and my work shed a light on different aspects of entertainment provided by television.

Though the effect of Western television on economic beliefs persisted during the 1990s, this must not be the case for the attitudes toward the GDR. If the main contribution of Western television was the entertainment of East Germans, the effect of different access to these broadcasts should not persist once everyone obtains the opportunity to watch and the situation in the GDR actually changes. Thus, I complement the analysis of Kern and Hainmueller (2009) by testing empirically whether the attitudes toward the GDR are still different between individuals from Dresden and other parts of the GDR after the reunification process started.

The empirical results presented in Table 13 confirm the earlier finding that before reunification, individuals without access to Western television were more skeptical toward several

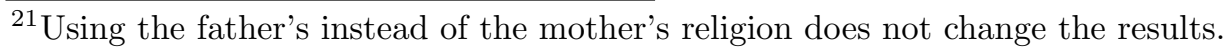


aspects of life in the GDR. Those living in the district of Dresden are significantly less content with the quality of reporting by state-controlled GDR media, less satisfied with life in the GDR in general, and significantly less optimistic about the future development of the economy and democracy in socialist states. Furthermore, the findings indicate a significantly positive relationship between access to Western television and the agreement with the Marxist-Leninist ideology.

Table 13: Attitudes toward the GDR And socialism, GDR, LATE 1980s

\begin{tabular}{|c|c|c|c|c|c|}
\hline & $\begin{array}{c}(1) \\
\text { GDR media }\end{array}$ & $\begin{array}{c}(2) \\
\text { Life GDR }\end{array}$ & $\begin{array}{c}(3) \\
\text { Socialist } \\
\text { economies }\end{array}$ & $\begin{array}{c}(4) \\
\text { Socialist } \\
\text { democracy }\end{array}$ & $\begin{array}{c}(5) \\
\text { Marx-Lenin }\end{array}$ \\
\hline Dresden & $\begin{array}{c}-0.1571^{* * *} \\
(0.0193)\end{array}$ & $\begin{array}{c}-0.0530^{* * *} \\
(0.0066)\end{array}$ & $\begin{array}{c}-0.0852^{* * *} \\
(0.0204)\end{array}$ & $\begin{array}{c}-0.0850^{* *} \\
(0.0246)\end{array}$ & $\begin{array}{c}-0.0708^{* * *} \\
(0.0118)\end{array}$ \\
\hline Age & $\begin{array}{l}-0.0023 \\
(0.0115)\end{array}$ & $\begin{array}{l}-0.0055 \\
(0.0083)\end{array}$ & $\begin{array}{c}-0.0470^{* * *} \\
(0.0064)\end{array}$ & $\begin{array}{l}-0.0173 \\
(0.0144)\end{array}$ & $\begin{array}{c}0.0432^{* * *} \\
(0.0119)\end{array}$ \\
\hline $\mathrm{Age}^{2}$ & $\begin{array}{c}0.0001 \\
(0.0002)\end{array}$ & $\begin{array}{c}0.0001 \\
(0.0001)\end{array}$ & $\begin{array}{c}0.0007 * * * \\
(0.0001)\end{array}$ & $\begin{array}{c}0.0003 \\
(0.0002)\end{array}$ & $\begin{array}{c}-0.0005^{* *} \\
(0.0002)\end{array}$ \\
\hline Female & $\begin{array}{c}0.1538 * * * \\
(0.0314)\end{array}$ & $\begin{array}{c}0.0379^{* * * *} \\
(0.0136)\end{array}$ & $\begin{array}{c}0.0749 * * * \\
(0.0194)\end{array}$ & $\begin{array}{c}0.0663^{* *} \\
(0.0225)\end{array}$ & $\begin{array}{c}0.1349^{* * *} \\
(0.0327)\end{array}$ \\
\hline Married & $\begin{array}{c}-0.0649 * * * \\
(0.0173)\end{array}$ & $\begin{array}{l}-0.0142 \\
(0.0297)\end{array}$ & $\begin{array}{l}-0.0035 \\
(0.0186)\end{array}$ & $\begin{array}{l}-0.0159 \\
(0.0209)\end{array}$ & $\begin{array}{c}0.0157 \\
(0.0276)\end{array}$ \\
\hline Widowed or divorced & $\begin{array}{c}0.0155 \\
(0.0273)\end{array}$ & $\begin{array}{l}-0.0246 \\
(0.0396)\end{array}$ & $\begin{array}{l}-0.0239 \\
(0.0581)\end{array}$ & $\begin{array}{c}0.0162 \\
(0.0699)\end{array}$ & $\begin{array}{l}0.0274^{*} \\
(0.0131)\end{array}$ \\
\hline Children & $\begin{array}{c}0.0422 \\
(0.0321)\end{array}$ & $\begin{array}{c}0.0216 \\
(0.0213)\end{array}$ & $\begin{array}{c}0.0510 \\
(0.0410)\end{array}$ & $\begin{array}{r}0.0634^{* *} \\
(0.0265)\end{array}$ & $\begin{array}{l}-0.0325 \\
(0.0344)\end{array}$ \\
\hline University degree & $\begin{array}{c}-0.1933^{* * *} \\
(0.0318)\end{array}$ & $\begin{array}{c}0.0122 \\
(0.0363)\end{array}$ & $\begin{array}{l}-0.0484^{*} \\
(0.0247)\end{array}$ & $\begin{array}{l}-0.0943 \\
(0.0507)\end{array}$ & $\begin{array}{c}-0.0441^{*} \\
(0.0222)\end{array}$ \\
\hline Net income & $\begin{array}{c}0.0128 \\
(0.0104)\end{array}$ & $\begin{array}{l}-0.0003 \\
(0.0032)\end{array}$ & $\begin{array}{c}0.0039 \\
(0.0052)\end{array}$ & $\begin{array}{c}0.0078 \\
(0.0042)\end{array}$ & $\begin{array}{c}0.0065 \\
(0.0072)\end{array}$ \\
\hline Intermediate education & $\begin{array}{c}-0.0836^{* * *} \\
(0.0323)\end{array}$ & $\begin{array}{c}0.0565^{* * *} \\
(0.0139)\end{array}$ & $\begin{array}{l}-0.0398 \\
(0.0313)\end{array}$ & $\begin{array}{l}-0.0566 \\
(0.0381)\end{array}$ & $\begin{array}{c}0.0791 \\
(0.0438)\end{array}$ \\
\hline High education & $\begin{array}{l}-0.0776 \\
(0.0515)\end{array}$ & $\begin{array}{c}0.0706 \\
(0.0442)\end{array}$ & $\begin{array}{c}-0.0851^{* * *} \\
(0.0205)\end{array}$ & $\begin{array}{l}-0.0407 \\
(0.0413)\end{array}$ & $\begin{array}{c}0.2301^{* * *} \\
(0.0433)\end{array}$ \\
\hline Population density & $\begin{array}{c}-0.0002^{* *} \\
(0.0001)\end{array}$ & $\begin{array}{c}-0.0001^{*} \\
(0.0000)\end{array}$ & $\begin{array}{l}-0.0001 \\
(0.0001)\end{array}$ & $\begin{array}{l}-0.0001 \\
(0.0001)\end{array}$ & $\begin{array}{c}-0.0002^{* * *} \\
(0.0001)\end{array}$ \\
\hline Industrial employment & $\begin{array}{c}-0.0139^{*} \\
(0.0073)\end{array}$ & $\begin{array}{c}-0.0063^{* *} \\
(0.0028)\end{array}$ & $\begin{array}{l}-0.0116 \\
(0.0083)\end{array}$ & $\begin{array}{l}-0.0070 \\
(0.0100)\end{array}$ & $\begin{array}{c}-0.0174^{* * *} \\
(0.0045)\end{array}$ \\
\hline Agricultural employment & $\begin{array}{l}-0.0222 \\
(0.0134)\end{array}$ & $\begin{array}{l}-0.0053 \\
(0.0051)\end{array}$ & $\begin{array}{l}-0.0143 \\
(0.0159)\end{array}$ & $\begin{array}{l}-0.0103 \\
(0.0192)\end{array}$ & $\begin{array}{c}-0.0270^{* *} \\
(0.0077)\end{array}$ \\
\hline Pseudo R2 & 0.0437 & 0.0488 & 0.0279 & & \\
\hline Observations & 2571 & 2603 & 2607 & 2603 & 2598 \\
\hline
\end{tabular}

Notes: Probit regressions (marginal effects are shown). The dependent variables equal one for respondents who (1) feel well informed by GDR media (GDR media), (2) like living in the GDR (Life GDR), are confident in the development of (3) the economy of socialist countries (Socialist economies) and (4) the socialist democracy in the GDR (Socialist democracy), and (5) agree with the Marxist-Leninist world view (Marx-Lenin). Omitted categories are male, never married, and finished $8^{\text {th }}$ grade (or less) in school. Robust standard errors in parentheses, clustered at district level. $* * * / * * / *$ denotes significance at the $1 \% / 5 \% / 10 \%$ level.

Table 14 presents the findings of the analysis using data from the SOEP for the 1990s to 
Table 14: Attitudes toward the GDR And HAPPINESs, FRG, 1990s

\begin{tabular}{|c|c|c|c|c|c|}
\hline & $\begin{array}{c}1) \\
\text { Social security } \\
\text { GDR (1990) }\end{array}$ & $\begin{array}{c}(2) \\
\text { Democracy } \\
\text { GDR (1990) }\end{array}$ & $\begin{array}{c}(3) \\
\text { Life standard } \\
\text { GDR (1991-94) }\end{array}$ & $\begin{array}{c}(4) \\
\text { Happiness } \\
(1990-99)\end{array}$ & $\begin{array}{c}(5) \\
\text { Expected happiness } \\
\text { in } 5 \text { yrs. (1990-99) }\end{array}$ \\
\hline Dresden & $\begin{array}{c}0.0218 \\
(0.0248)\end{array}$ & $\begin{array}{c}-0.0047 \\
(0.0353)\end{array}$ & $\begin{array}{c}0.0496^{* *} \\
(0.0213)\end{array}$ & $\begin{array}{l}-0.0007 \\
(0.0132)\end{array}$ & $\begin{array}{c}0.0319^{* *} \\
(0.0144)\end{array}$ \\
\hline Age & $\begin{array}{c}-0.0089 \\
(0.0163)\end{array}$ & $\begin{array}{c}-0.0155 \\
(0.0185)\end{array}$ & $\begin{array}{c}-0.0151^{* *} \\
(0.0065)\end{array}$ & $\begin{array}{c}-0.0321^{* * *} \\
(0.0080)\end{array}$ & $\begin{array}{c}-0.0001 \\
(0.0054)\end{array}$ \\
\hline $\mathrm{Age}^{2}$ & $\begin{array}{c}0.0001 \\
(0.0004)\end{array}$ & $\begin{array}{c}0.0003 \\
(0.0004)\end{array}$ & $\begin{array}{l}0.0002^{*} \\
(0.0001)\end{array}$ & $\begin{array}{c}0.0005^{* *} \\
(0.0002)\end{array}$ & $\begin{array}{c}-0.0003^{*} \\
(0.0001)\end{array}$ \\
\hline $\mathrm{Age}^{3}$ & $\begin{array}{l}-0.0000 \\
(0.0000)\end{array}$ & $\begin{array}{l}-0.0000 \\
(0.0000)\end{array}$ & $\begin{array}{l}-0.0000 \\
(0.0000)\end{array}$ & $\begin{array}{l}-0.0000 \\
(0.0000)\end{array}$ & $\begin{array}{c}0.0000^{* *} \\
(0.0000)\end{array}$ \\
\hline Female & $\begin{array}{c}0.0081 \\
(0.0137)\end{array}$ & $\begin{array}{c}-0.0140 \\
(0.0109)\end{array}$ & $\begin{array}{l}-0.0049 \\
(0.0077)\end{array}$ & $\begin{array}{c}-0.0048 \\
(0.0073)\end{array}$ & $\begin{array}{c}0.0011 \\
(0.0071)\end{array}$ \\
\hline Father's education & $\begin{array}{l}-0.0075 \\
(0.0189)\end{array}$ & $\begin{array}{l}-0.0224 \\
(0.0240)\end{array}$ & $\begin{array}{c}-0.0218^{* * *} \\
(0.0059)\end{array}$ & $\begin{array}{c}0.0022 \\
(0.0052)\end{array}$ & $\begin{array}{l}0.0124^{*} \\
(0.0064)\end{array}$ \\
\hline Married & $\begin{array}{c}0.0355 \\
(0.0355)\end{array}$ & $\begin{array}{c}0.0036 \\
(0.0385)\end{array}$ & $\begin{array}{c}-0.0326^{* *} \\
(0.0165)\end{array}$ & $\begin{array}{c}0.0481^{* * *} \\
(0.0164)\end{array}$ & $\begin{array}{c}0.0074 \\
(0.0212)\end{array}$ \\
\hline Married but separated & $\begin{array}{c}0.0626 \\
(0.1226)\end{array}$ & $\begin{array}{c}-0.0093 \\
(0.0818)\end{array}$ & $\begin{array}{c}-0.1077^{*} \\
(0.0559)\end{array}$ & $\begin{array}{c}-0.0946^{* * *} \\
(0.0286)\end{array}$ & $\begin{array}{c}0.0102 \\
(0.0426)\end{array}$ \\
\hline Widowed or divorced & $\begin{array}{c}-0.0228 \\
(0.0532)\end{array}$ & $\begin{array}{c}-0.0220 \\
(0.0534)\end{array}$ & $\begin{array}{c}-0.0287 \\
(0.0240)\end{array}$ & $\begin{array}{c}0.0267 \\
(0.0193)\end{array}$ & $\begin{array}{l}0.0323^{*} \\
(0.0168)\end{array}$ \\
\hline Not employed & $\begin{array}{c}-0.0697 \\
(0.0451)\end{array}$ & $\begin{array}{c}0.0514 \\
(0.0389)\end{array}$ & $\begin{array}{c}-0.0533^{*} \\
(0.0326)\end{array}$ & $\begin{array}{l}-0.0335 \\
(0.0405)\end{array}$ & $\begin{array}{c}0.0313 \\
(0.0268)\end{array}$ \\
\hline Retired & $\begin{array}{c}0.0741^{* *} \\
(0.0376)\end{array}$ & $\begin{array}{c}0.1123^{* * *} * \\
(0.0385)\end{array}$ & $\begin{array}{l}-0.0085 \\
(0.0161)\end{array}$ & $\begin{array}{c}0.0111 \\
(0.0224)\end{array}$ & $\begin{array}{c}0.0273 \\
(0.0171)\end{array}$ \\
\hline Unemployed & & & $\begin{array}{c}-0.0146^{*} \\
(0.0082)\end{array}$ & $\begin{array}{c}-0.1622^{* * *} \\
(0.0092)\end{array}$ & $\begin{array}{c}-0.0674^{* * *} \\
(0.0132)\end{array}$ \\
\hline Self employed & $\begin{array}{c}0.0624 \\
(0.0574)\end{array}$ & $\begin{array}{c}0.0149 \\
(0.0523)\end{array}$ & $\begin{array}{c}0.0119 \\
(0.0191)\end{array}$ & $\begin{array}{c}0.0062 \\
(0.0183)\end{array}$ & $\begin{array}{c}0.0897^{* * *} \\
(0.0221)\end{array}$ \\
\hline Civil servant & & & $\begin{array}{c}0.0117 \\
(0.0480)\end{array}$ & $\begin{array}{c}0.1035^{* *} \\
(0.0478)\end{array}$ & $\begin{array}{l}0.1451^{*} \\
(0.0740)\end{array}$ \\
\hline White collar & $\begin{array}{c}-0.0050 \\
(0.0163)\end{array}$ & $\begin{array}{c}0.0248 \\
(0.0270)\end{array}$ & $\begin{array}{l}-0.0006 \\
(0.0130)\end{array}$ & $\begin{array}{c}0.0460^{* * * *} \\
(0.0141)\end{array}$ & $\begin{array}{l}0.0505^{* *} \\
(0.0247)\end{array}$ \\
\hline University degree & $\begin{array}{c}-0.0606^{* *} \\
(0.0263)\end{array}$ & $\begin{array}{c}0.0120 \\
(0.0366)\end{array}$ & $\begin{array}{l}-0.0113 \\
(0.0114)\end{array}$ & $\begin{array}{c}0.0093 \\
(0.0171)\end{array}$ & $\begin{array}{c}0.0027 \\
(0.0108)\end{array}$ \\
\hline High education & $\begin{array}{l}-0.0759 \\
(0.0537)\end{array}$ & $\begin{array}{c}0.0466 \\
(0.0626)\end{array}$ & $\begin{array}{c}-0.0716^{* * *} \\
(0.0194)\end{array}$ & $\begin{array}{c}0.0087 \\
(0.0425)\end{array}$ & $\begin{array}{c}0.0122 \\
(0.0286)\end{array}$ \\
\hline Intermediate education & $\begin{array}{c}-0.0188 \\
(0.0449)\end{array}$ & $\begin{array}{c}0.0514 \\
(0.0429)\end{array}$ & $\begin{array}{c}-0.0352^{* *} \\
(0.0177)\end{array}$ & $\begin{array}{c}0.0153 \\
(0.0276)\end{array}$ & $\begin{array}{c}0.0107 \\
(0.0218)\end{array}$ \\
\hline No. persons in household & $\begin{array}{l}-0.0083 \\
(0.0190)\end{array}$ & $\begin{array}{l}-0.0099 \\
(0.0161)\end{array}$ & $\begin{array}{l}0.0123^{*} \\
(0.0069)\end{array}$ & $\begin{array}{c}-0.0475^{* * *} \\
(0.0120)\end{array}$ & $\begin{array}{l}-0.0157 \\
(0.0113)\end{array}$ \\
\hline No. children in household & $\begin{array}{c}0.0155 \\
(0.0254)\end{array}$ & $\begin{array}{c}0.0141 \\
(0.0182)\end{array}$ & $\begin{array}{l}-0.0065 \\
(0.0085)\end{array}$ & $\begin{array}{c}0.0416^{* * *} \\
(0.0073)\end{array}$ & $\begin{array}{c}0.0144^{* *} * \\
(0.0064)\end{array}$ \\
\hline Log. household income & & & & $\begin{array}{c}0.1613^{* * *} \\
(0.0151)\end{array}$ & $\begin{array}{c}0.1060 * * * \\
(0.0151)\end{array}$ \\
\hline Low household income & $\begin{array}{c}0.0342 \\
(0.0461)\end{array}$ & $\begin{array}{c}0.0289 \\
(0.0391)\end{array}$ & $\begin{array}{c}-0.0077 \\
(0.0150)\end{array}$ & & \\
\hline Intermed. household income & $\begin{array}{c}0.0203 \\
(0.0268)\end{array}$ & $\begin{array}{c}0.0270 \\
(0.0386)\end{array}$ & $\begin{array}{c}-0.0105 \\
(0.0123)\end{array}$ & & \\
\hline Currently living in West Germany & & & $\begin{array}{c}0.1867 * * * \\
(0.0510)\end{array}$ & $\begin{array}{c}0.1028^{*} \\
(0.0556)\end{array}$ & $\begin{array}{c}0.1728^{* * *} \\
(0.0556)\end{array}$ \\
\hline Unemployment experience & $\begin{array}{c}0.0125 \\
(0.0102)\end{array}$ & $\begin{array}{c}-0.0395^{*} \\
(0.0234)\end{array}$ & $\begin{array}{c}-0.0084^{*} \\
(0.0051)\end{array}$ & $\begin{array}{c}-0.0296^{* * *} \\
(0.0054)\end{array}$ & $\begin{array}{c}-0.0229^{* * *} * \\
(0.0042)\end{array}$ \\
\hline Unemployment rate (state level) & $\begin{array}{l}0.0256^{*} \\
(0.0141)\end{array}$ & $\begin{array}{c}0.0149 \\
(0.0189)\end{array}$ & $\begin{array}{c}0.0215^{* * *} * \\
(0.0054)\end{array}$ & $\begin{array}{c}0.0023 \\
(0.0054)\end{array}$ & $\begin{array}{c}0.0043 \\
(0.0054)\end{array}$ \\
\hline Year FE & NO & NO & YES & YES & YES \\
\hline Pseudo R2 & 0.0145 & 0.0118 & 0.0404 & 0.0517 & 0.0682 \\
\hline Observations & 2994 & 2991 & 11747 & 20011 & 19927 \\
\hline
\end{tabular}

Notes: Probit regressions (marginal effects are shown). The dependent variables equals one for respondents who are satisfied with (1) the social security (Social security GDR, or (2) the democracy in the GDR (Democracy GDR), the (3) general standard of living in the GDR (Life standard), and who stated to be (4) satisfied with life in general (Happiness) or (5) expect to be satisfied in five years (Expected happiness). Omitted categories are male, never married, being still in education, being born before 1931, less than 9 years of schooling, and an available household income above the $75^{\text {th }}$ percentile in 1992 . The unemployment rate is measured as the average unemployment rate in the state of residence between 1991 and (n) 1995 in the analysis of social security and democracy in the GDR. Robust standard errors in parentheses, clustered at the level of the regional
planning units or in case of (expected) happiness at Nuts2-level. ***/**/* denotes significance at the $1 \% / 5 \% / 10 \%$ level. 
test the persistence of differential attitudes after the reunification. In summer 1990, soon after the inner-German border was opened, no significant differences in the assessment of the social security and the democracy in the GDR are observable.

However, individuals from the Dresden-district are relatively more satisfied with the standard of living in East Germany after reunification. While individuals who had lived in the district of Dresden before reunification and those from other parts of the GDR do not differ significantly with respect to their general happiness during the 1990s, those from Dresden are more optimistic toward their future life happiness.

\section{Conclusion}

This paper exploits a natural experiment on West German television reception in the former GDR to analyze its impact on East Germans' beliefs before and up to one decade after reunification. I show that the availability of Western television has made East Germans more inclined to believe that effort rather than luck determines success in life. Moreover, Western television also affected attitudes toward the GDR and socialism. While the exposure to West German media is reflected in personal beliefs up to ten years after reunification, differences in attitudes diminished soon after the fall of the Berlin wall.

I argue that the regime-stabilizing effect of Western television and its impact on East Germans' beliefs reflect two different aspects of entertainment programs (e.g. movies or soap operas). In the short run, these programs made life in real-existing socialism more bearable. Beyond entertainment, Western soap operas and movies also provided additional signals about the relationship between effort (as opposed to predetermined factors such as luck) and success and by this affected the corresponding beliefs of East Germans. Those elementary beliefs remain rather stable once they are formed in a critical age (e.g. during early adulthood; see Giuliano and Spilimbergo, 2009), which can explain the persistence of the effect of differential access to Western television during the 1990s.

It might be true that the main findings of this paper are driven by some Dresden-specific factor. Given the robustness of the result to various additional tests, I am, however, confident that West German television has indeed affected the beliefs and attitudes of East Germans. Hence, state-controlled media seem to have been a part of socialization that has left its marks on East Germans minds. 
This analysis is based on exposure to Western television in the GDR and, thus, on a specific situation. Still, it indicates that the role of information provided by mass media should not be overlooked for belief formation. Since beliefs on the drivers of success are also correlated with voters' preferences for redistribution, television may affect policy outcomes even if that may not be intended but may just be a byproduct of providing entertainment.

\section{References}

Ai, C. And E. C. Norton (2003): "Interaction terms in logit and probit models," Economic Letters, 80, 123-129.

Alesina, A. And G.-M. Angeletos (2005): "Fairness and Redistribution," American Economic Review, 95, 960-980.

Alesina, A. And N. Fuchs-Schündeln (2007): "Good-Bye Lenin (or Not?): The Effect of Communism on People's Preferences," The American Economic Review, 97, 1507-1528.

Alesina, A. And P. Giuliano (2009): "Preferences for Redistribution," NBER Working Papers, 14825.

Alesina, A. And E. Glaeser (2004): Fighting Poverty in the US and Europe: A World of Difference, New York.

Benabou, R. And J. Tirole (2006): "Belief in a Just World and Redistributive Politics," The Quarterly Journal of Economics, 121, 699-746.

Bundesinstitut für BAu-, Stadt- und RAumforschung (BBSR) (various years): Indikatoren und Karten zur Raum- und Stadtentwicklung (INKAR), Bonn.

Bursztyn, L. And D. Cantoni (2012): "A tear in the Iron Curtain: The impact of western television on consumption behavior," Munich Discussion Paper No. 2012-19.

Chong, A., S. Duryea, And E. La Ferrara (2008): "Soap Operas and Fertility: Evidence from Brazil," CEPR Discussion Papers, 6785.

Chong, A. And E. La Ferrara (2009): "Television and Divorce: Evidence from Brazilian Novelas," Journal of the European Economic Association, 7, 458-468.

Corneo, G. And H. Grüner (2002): "Individual Preferences for Political Redistribution," Journal of Public Economics, 83, 83-107. 
DellaVigna, S. And E. Kaplan (2007): "The Fox News Effect: Media Bias and Voting," Quarterly Journal of Economics, 122, 1187-1234.

Di Tella, R., S. Galiani, and E. Schargrodsky (2007): "The Formation of Beliefs: Evidence from the Allocation of Land Titles to Squatters," Quarterly Journal of Economics, 122, 209-241.

Enikolopov, R., M. Petrova, And E. Zhuravskaya (2011): "Media and Political Persuasion: Evidence from Russia," American Economic Review, 101, 3253-3285.

Etzkorn, K. P. And H.-J. Stiehler (1998): “The 'Valley of the Clueless' - Results From an Historical Experiment," The European Journal of Communication Research, 23, $271-298$.

Fong, C. (2001): "Social Preferences, Self Interest, and the Demand for Redistribution," Journal of Public Economics, 80, 225-246.

GDR Statistical Office (various years): Statistical Yearbook of the German Democratic Republic, Berlin: Staatsverlag der Deutschen Demokratischen Republik.

Gentzkow, M. A. And J. M. Shapiro (2004): "Media, Education and Anti-Americanism in the Muslim World," Journal of Economic Perspectives, 18, 117-133.

Giuliano, P. And A. Spilimbergo (2009): "Growing Up in a Recession: Beliefs and the Macroeconomy," NBER Working Paper, 15321.

Grundmann, S. (1997): "Territorialplanung in der DDR: Indikatoren zur Analyse regionaler Disparitäten - Die sozial-räumliche Struktur der DDR in den 80er Jahren," in Regionale Strukturen im Wandel, ed. by A. Becker, Opladen, 7-44.

Heineck, G. And B. Süssmuth (2010): “A Different Look at Lenin's Legacy: Trust, Risk, Fairness and Cooperativeness in the Two Germanies," IZA Discussion Paper No. 5219.

Hesse, K. R. (1988): Westmedien in der DDR. Nutzung, Image und Auswirkungen bundesrepublikanischen Hörfunks und Fernsehens, Köln.

Jensen, R. And E. Oster (2009): "The Power of TV: Cable Television and Women's Status in India," The Quarterly Journal of Economics, 124, 1057-1094.

Kern, H. L. And J. Hainmueller (2009): "Opium for the Masses: How Foreign Media Can Stabilze Authorien Regimes," Political Analysis, 17, 377-399. 
KIND, G. (1997): "Territorialentwicklung und Territorialplanung in der DDR: Ergebnisse und Auswirkungen auf die Raumstruktur Deutschlands," in Regionale Strukturen im Wandel, ed. by A. Becker, Opladen, 17-103.

Maretzke, S. (1991): "Tendenzen der Wanderungsentwicklung zwischen den alten und neuen Bundesländern im Zeitraum 1989 und 1990," in Raumentwicklung in den alten und neuen Bundesländern. Arbeitsbeiträge zum Raumordnungsbericht der Bundesregierung 1991, ed. by Bundesforschungsanstalt für Landeskunde und Raumordnung, Bonn, 10-21.

Meyen, M. (2002): "Kollektive Ausreise? Zur Reichweite ost- und westdeutscher Fernsehprogramme in der DDR," Publizistik, 47, 200-220.

(2003): Einschalten, Umschalten, Ausschalten? Das Fernsehen im DDR-Alltag, Leipzig.

Piketty, T. (1995): "Social Mobility and Redistributive Politics," Quarterly Journal of Economics, 3, 551-585.

Prat, A. And D. Strömberg (2011): "The Political Economy of Mass Media," CEPR Discussion Paper No. 8246 .

Statistisches Reichsamt Germany (1926): Statistical Yearbook of the German Reich 1924, Berlin: Schmidt Berlin.

StiehleR, H.-J. (1998): "Das Tal der Ahnungslosen. Erforschung der TV-Rezeption zur Zeit der DDR." in Medienrezeption seit 1945. Forschungsbefunde und Forschungsperspektiven., ed. by W. Klingler, G. Roters, and M. Gerhards, Baden-Baden, 187-202.

(2001): Leben ohne Westfernsehen: Studien zur Medienwirkung und Mediennutzung in der Region Dresden in den 80er Jahren, Leipzig.

Suhrcke, M. (2001): "Preferences for Inequality: East vs. West," Innocenti Working Paper, No. 89.

Wagner, G. G., J. R. Frick, And J. Schupp (2007): "The German Socio-Economic Panel Study (SOEP) - Scope, Evolution and Enhancements," SOEP Papers, No. 1.

Zentralinstitut Für Jugendforschung (1989): "Politisches Klima und gesellschaftliche Bedingungen in der DDR 1989 (ZA 6008)," Zentralarchiv für Empirische Sozialforschung (GESIS-ZA). 


\section{Appendix}

Table 15: Summary Statistics - GDR 1988/89

\begin{tabular}{|c|c|c|c|c|c|c|c|c|c|c|c|c|c|c|c|c|c|}
\hline \multirow[b]{3}{*}{ Variables } & \multirow[b]{3}{*}{ Obs. } & \multicolumn{4}{|c|}{ All observations } & \multicolumn{3}{|c|}{ Treatment group } & \multicolumn{9}{|c|}{ Control group } \\
\hline & & \multirow[b]{2}{*}{ Mean } & \multirow[b]{2}{*}{ Std.Dev. } & \multirow[b]{2}{*}{ Min. } & \multirow[b]{2}{*}{ Max. } & \multicolumn{3}{|c|}{ Dresden } & \multicolumn{3}{|c|}{ GDR } & \multicolumn{3}{|c|}{ excl. Berlin } & \multicolumn{3}{|c|}{ Leipzig \& Karl-Marx-Stadt } \\
\hline & & & & & & Obs. & Mean & Std.Dev. & Obs. & Mean & Std.Dev. & Obs. & Mean & Std.Dev. & Obs. & Mean & Std.Dev. \\
\hline \multicolumn{18}{|c|}{ Baseline regression } \\
\hline Effort pays off & 3381 & 0.58 & 0.49 & 0 & 1 & 736 & 0.53 & 0.50 & 2645 & 0.60 & 0.49 & 2254 & 0.61 & 0.49 & 860 & 0.62 & 0.49 \\
\hline Age & 3497 & 23.09 & 6.38 & 15 & 50 & 770 & 23.36 & 6.36 & 2727 & 23.02 & 6.38 & 2314 & 22.97 & 6.19 & 891 & 24.13 & 6.74 \\
\hline Female & 3526 & 0.48 & 0.50 & 0 & 1 & 777 & 0.51 & 0.50 & 2749 & 0.47 & 0.50 & 2332 & 0.48 & 0.50 & 900 & 0.60 & 0.49 \\
\hline Never married & 3525 & 0.68 & 0.47 & 0 & 1 & 777 & 0.65 & 0.48 & 2748 & 0.69 & 0.46 & 2331 & 0.69 & 0.45 & 900 & 0.56 & 0.50 \\
\hline Married & 3525 & 0.28 & 0.45 & 0 & 1 & 777 & 0.32 & 0.47 & 2748 & 0.27 & 0.45 & 2331 & 0.27 & 0.45 & 900 & 0.40 & 0.49 \\
\hline Divorced/Widowed & 3525 & 0.04 & 0.19 & 0 & 1 & 777 & 0.04 & 0.18 & 2748 & 0.04 & 0.20 & 2331 & 0.04 & 0.19 & 900 & 0.04 & 0.20 \\
\hline Children & 3507 & 0.33 & 0.47 & 0 & 1 & 773 & 0.38 & 0.49 & 2734 & 0.31 & 0.46 & 2318 & 0.31 & 0.46 & 891 & 0.40 & 0.49 \\
\hline Net income & 2742 & 3.91 & 1.87 & 1 & 9 & 594 & 4.02 & 1.87 & 2148 & 3.88 & 1.86 & 1859 & 3.80 & 1.83 & 730 & 3.86 & 1.86 \\
\hline Low education & 3531 & 0.09 & 0.29 & 0 & 1 & 778 & 0.09 & 0.28 & 2753 & 0.10 & 0.29 & 2336 & 0.09 & 0.29 & 903 & 0.06 & 0.25 \\
\hline Intermed. education & 3531 & 0.80 & 0.40 & 0 & 1 & 778 & 0.81 & 0.40 & 2753 & 0.80 & 0.40 & 2336 & 0.81 & 0.39 & 903 & 0.81 & 0.40 \\
\hline High education & 3531 & 0.10 & 0.31 & 0 & 1 & 778 & 0.11 & 0.31 & 2753 & 0.10 & 0.30 & 2336 & 0.10 & 0.30 & 903 & 0.13 & 0.34 \\
\hline University & 3479 & 0.06 & 0.23 & 0 & 1 & 769 & 0.08 & 0.27 & 2710 & 0.05 & 0.22 & 2297 & 0.05 & 0.22 & 893 & 0.07 & 0.25 \\
\hline Population density & 3563 & 555.81 & 958.78 & 68 & 3174 & 784 & 254 & 0 & 2779 & 640.95 & 1070.39 & 2360 & 191.23 & 85.04 & 910 & 291.65 & 15.65 \\
\hline Industrial employment & 3563 & 38.50 & 7.73 & 24.3 & 48.1 & 784 & 42.8 & 0 & 2779 & 37.28 & 8.36 & 2360 & 39.41 & 7.24 & 910 & 45.60 & 3.78 \\
\hline Agricultural employment & 3563 & 9.37 & 5.05 & 1 & 22.2 & 784 & 8.1 & 0 & 2779 & 9.73 & 5.66 & 2360 & 11.28 & 4.67 & 910 & 6.70 & 1.06 \\
\hline \multicolumn{18}{|c|}{ Addtional variables } \\
\hline GDR media & 3455 & 0.36 & 0.48 & 0 & 1 & 758 & 0.27 & 0.44 & 2697 & 0.39 & 0.49 & 877 & 0.42 & 0.49 & & & \\
\hline Life GDR & 3520 & 0.91 & 0.28 & 0 & 1 & 775 & 0.85 & 0.35 & 2745 & 0.93 & 0.26 & 2327 & 0.93 & 0.26 & 897 & 0.92 & 0.27 \\
\hline Socialist economies & 3527 & 0.45 & 0.50 & 0 & 1 & 773 & 0.38 & 0.49 & 2754 & 0.47 & 0.50 & 2337 & 0.50 & 0.50 & 899 & 0.49 & 0.50 \\
\hline Socialist democracy & 3524 & 0.52 & 0.50 & 0 & 1 & 772 & 0.46 & 0.50 & 2752 & 0.53 & 0.50 & 2333 & 0.55 & 0.50 & 898 & 0.58 & 0.50 \\
\hline Marx-Lenin & 3516 & 0.65 & 0.48 & 0 & 1 & 775 & 0.60 & 0.49 & 2741 & 0.66 & 0.48 & 2323 & 0.66 & 0.47 & 894 & 0.69 & 0.46 \\
\hline Industrial production & 3563 & 8.38 & 2.82 & 2.5 & 12.5 & 784 & 10.7 & 0 & 2779 & 7.72 & 2.87 & 2360 & 8.12 & 2.95 & 910 & 11.07 & 2.16 \\
\hline Working age population & 3563 & 64.39 & 1.41 & 62.9 & 67.5 & 784 & 62.9 & 0 & 2779 & 64.82 & 1.32 & 2360 & 64.34 & 0.73 & 910 & 63.53 & 0.51 \\
\hline High educated workers & 3563 & 20.62 & 4.69 & 17 & 33 & 784 & 20.6 & 0 & 2779 & 20.63 & 5.31 & 2360 & 18.43 & 1.11 & 910 & 18.13 & 1.70 \\
\hline Border district & 3563 & 0.69 & 0.46 & 0 & 1 & 784 & 0 & 0 & 2779 & 0.88 & 0.33 & 2360 & 0.86 & 0.35 & 2360 & 0.70 & 0.46 \\
\hline Distance to Berlin & 3563 & 156.78 & 67.37 & 0 & 283.45 & 784 & 165.41 & 0 & 2779 & 154.34 & 76.10 & 2360 & 181.74 & 42.88 & 910 & 178.62 & 19.03 \\
\hline Theater visitors & 3563 & 0.002 & 0.0004 & 0.0008 & 0.003 & 784 & 0.0019 & 0 & 2779 & 0.0017 & 0.00045 & 2360 & 0.0015 & 0.0002 & 910 & 0.0014 & 0.00002 \\
\hline Theater & 1166 & 0.22 & 0.42 & 0 & 1 & 257 & 0.25 & 0.43 & 909 & 0.22 & 0.41 & 771 & 0.18 & 0.39 & 302 & 0.15 & 0.36 \\
\hline Cinema & 3522 & 0.43 & 0.50 & 0 & 1 & 777 & 0.50 & 0.50 & 2745 & 0.41 & 0.49 & 2329 & 0.38 & 0.49 & 898 & 0.37 & 0.48 \\
\hline Museum & 1165 & 0.42 & 0.49 & 0 & 1 & 257 & 0.45 & 0.50 & 908 & 0.41 & 0.49 & 771 & 0.40 & 0.49 & 304 & 0.41 & 0.49 \\
\hline
\end{tabular}


Table 16: Summary statistics - SOEP Data

\begin{tabular}{|c|c|c|c|c|c|c|c|c|c|c|c|c|c|c|c|c|c|c|c|c|}
\hline \multirow[b]{2}{*}{ Variable } & \multirow[b]{2}{*}{ Obs } & \multicolumn{4}{|c|}{ All observations } & \multicolumn{3}{|c|}{$\begin{array}{c}\text { Treatment group } \\
\text { Dresden }\end{array}$} & \multicolumn{3}{|c|}{$\begin{array}{l}\text { excl. Greifswald- } \\
\text { Stralsund }\end{array}$} & \multicolumn{4}{|c|}{$\begin{array}{l}\text { Control group } \\
\text { lin \& } \\
\text { Stralsund }\end{array}$} & \multicolumn{2}{|c|}{ Saxony } & \multicolumn{3}{|c|}{ East } \\
\hline & & Mean & Std.Dev. & Min & Max & Obs & Mean & Std.Dev. & Obs & Mean & Std.Dev. & Obs & Mean & Std.Dev. & Obs & Mean & Std.Dev. & Obs & Mean & Std.Dev. \\
\hline \multicolumn{21}{|c|}{ Baseline regression } \\
\hline Luck & 13910 & 0.22 & 0.41 & 0 & 1 & 1385 & 0.25 & 0.43 & 11819 & 0.22 & 0.41 & 10928 & 0.22 & 0.42 & 2731 & 0.22 & 0.42 & 3018 & 0.22 & 0.42 \\
\hline Age & 36715 & 43.54 & 16.4 & 17 & 98 & 3734 & 42.39 & 16.16 & 31786 & 43.65 & 16.42 & 29383 & 43.74 & 16.52 & 7284 & 45.13 & 16.62 & 8159 & 44.64 & 16.80 \\
\hline Female & 36715 & 0.52 & 0.50 & 0 & 1 & 3734 & 0.53 & 0.50 & 31786 & 0.52 & 0.50 & 29383 & 0.52 & 0.50 & 7284 & 0.53 & 0.50 & 8159 & 0.52 & 0.50 \\
\hline Father's education & 31059 & 2.31 & 0.64 & 0 & 4 & 3252 & 2.35 & 0.65 & 26892 & 2.30 & 0.63 & 24857 & 2.28 & 0.61 & 6150 & 2.30 & 0.63 & 6726 & 2.25 & 0.59 \\
\hline Never married & 36460 & 0.21 & 0.41 & 0 & 1 & 3718 & 0.20 & 0.40 & 31560 & 0.21 & 0.41 & 29204 & 0.20 & 0.40 & 7252 & 0.18 & 0.39 & 8115 & 0.20 & 0.40 \\
\hline Married & 36301 & 0.66 & 0.47 & 0 & 1 & 3704 & 0.69 & 0.46 & 31422 & 0.66 & 0.47 & 29082 & 0.67 & 0.47 & 7222 & 0.68 & 0.47 & 8090 & 0.67 & 0.47 \\
\hline Married but separated & 36301 & 0.01 & 0.10 & 0 & 1 & 3704 & 0.01 & 0.09 & 31422 & 0.01 & 0.10 & 29082 & 0.01 & 0.10 & 7222 & 0.01 & 0.10 & 8090 & 0.01 & 0.10 \\
\hline Widowed or divorced & 36301 & 0.12 & 0.32 & 0 & 1 & 3704 & 0.11 & 0.31 & 31422 & 0.12 & 0.32 & 29082 & 0.12 & 0.32 & 7222 & 0.12 & 0.33 & 8090 & 0.13 & 0.33 \\
\hline Not employed & 36173 & 0.03 & 0.17 & 0 & 1 & 3691 & 0.03 & 0.17 & 31318 & 0.03 & 0.17 & 28964 & 0.03 & 0.17 & 7200 & 0.03 & 0.17 & 8064 & 0.03 & 0.18 \\
\hline Pensioner & 36173 & 0.19 & 0.40 & 0 & 1 & 3691 & 0.17 & 0.38 & 31318 & 0.20 & 0.40 & 28964 & 0.20 & 0.40 & 7200 & 0.21 & 0.41 & 8064 & 0.22 & 0.41 \\
\hline In education & 36173 & 0.05 & 0.21 & 0 & 1 & 3691 & 0.05 & 0.21 & 31318 & 0.05 & 0.21 & 28964 & 0.04 & 0.20 & 7200 & 0.04 & 0.20 & 8064 & 0.04 & 0.20 \\
\hline Unemployed & 36173 & 0.10 & 0.30 & 0 & 1 & 3691 & 0.09 & 0.29 & 31318 & 0.10 & 0.31 & 28964 & 0.11 & 0.31 & 7200 & 0.11 & 0.31 & 8064 & 0.12 & 0.32 \\
\hline Self-employed & 36173 & 0.04 & 0.20 & 0 & 1 & 3691 & 0.05 & 0.22 & 31318 & 0.04 & 0.20 & 28964 & 0.04 & 0.19 & 7200 & 0.04 & 0.18 & 8064 & 0.04 & 0.20 \\
\hline Civil servant & 36173 & 0.01 & 0.11 & 0 & 1 & 3691 & 0.007 & 0.08 & 31318 & 0.01 & 0.11 & 28964 & 0.01 & 0.10 & 7200 & 0.009 & 0.09 & 8064 & 0.01 & 0.11 \\
\hline White collar & 36269 & 0.28 & 0.45 & 0 & 1 & 3697 & 0.29 & 0.45 & 31401 & 0.27 & 0.45 & 29041 & 0.27 & 0.44 & 7219 & 0.27 & 0.44 & 8083 & 0.25 & 0.43 \\
\hline Blue collar & 36269 & 0.24 & 0.43 & 0 & 1 & 3697 & 0.24 & 0.43 & 31401 & 0.24 & 0.43 & 29041 & .25 & 0.43 & 7219 & 0.26 & 0.44 & 8083 & 0.23 & 0.42 \\
\hline University degree & 36290 & 0.23 & 0.42 & 0 & 1 & 3710 & 0.25 & 0.43 & 31402 & 0.23 & 0.42 & 29032 & 0.22 & 0.41 & 7196 & 0.21 & 0.41 & 8073 & 0.22 & 0.41 \\
\hline High education & 35912 & 0.13 & 0.34 & 0 & 1 & 3674 & 0.15 & 0.35 & 31070 & 0.13 & 0.34 & 28759 & 0.12 & 0.32 & 7157 & 0.13 & 0.34 & 7981 & 0.12 & 0.33 \\
\hline Intermed. education & 35597 & 0.79 & 0.41 & 0 & 1 & 3640 & 0.78 & 0.42 & 30795 & 0.79 & 0.41 & 28498 & 0.80 & 0.40 & 7121 & 0.78 & 0.41 & 24836 & 0.80 & 0.40 \\
\hline Low education & 35642 & 0.08 & 0.27 & 0 & 1 & 3644 & 0.08 & 0.27 & 30834 & 0.08 & 0.27 & 28535 & 0.08 & 0.27 & 7124 & 0.09 & 0.28 & 7938 & 0.10 & 0.31 \\
\hline $\begin{array}{l}\text { No. persons in house- } \\
\text { hold }\end{array}$ & 36715 & 3.01 & 1.19 & 1 & 8 & 3734 & 3.22 & 1.14 & 31786 & 2.99 & 1.20 & 29383 & 3.01 & 1.20 & 7284 & 2.80 & 1.06 & 8159 & 2.91 & 1.14 \\
\hline $\begin{array}{l}\text { No. children in house- } \\
\text { hold }\end{array}$ & 66357 & 0.83 & 0.99 & 0 & 6 & 6970 & 1.06 & 1.01 & 57477 & 0.82 & 0.99 & 52866 & 0.81 & 1.00 & 12898 & 0.69 & 0.92 & & & \\
\hline $\begin{array}{l}\text { Available household in- } \\
\text { come }\end{array}$ & 28283 & 10.14 & 0.50 & 3.47 & 12.23 & 2859 & 10.19 & 0.49 & 24504 & 10.14 & 0.50 & 22638 & 10.13 & 0.50 & 5624 & 10.09 & 0.47 & 6248 & 10.07 & 0.47 \\
\hline West Germany & 36715 & 0.03 & 0.17 & 0 & 1 & 3734 & 0.04 & 0.19 & 31786 & 0.03 & 0.16 & 29383 & 0.03 & 0.16 & 7284 & 0.04 & 0.20 & 8159 & 0.03 & 0.18 \\
\hline $\begin{array}{l}\text { Unemployment experi- } \\
\text { ence }\end{array}$ & 35404 & 0.36 & 0.93 & 0 & 19 & 3626 & 0.28 & 0.73 & 30665 & 0.36 & 0.95 & 28346 & 0.36 & 0.96 & 7049 & 0.36 & 0.92 & 7812 & 0.39 & 0.94 \\
\hline $\begin{array}{l}\text { Unemployment rate } \\
\text { (state) }\end{array}$ & 32332 & 15.82 & 3.25 & 3.7 & 21.7 & 3286 & 14.91 & 3.21 & 28001 & 15.89 & 3.24 & 25885 & 16.02 & 3.25 & 6407 & 14.99 & 3.27 & 7169 & 15.32 & 3.10 \\
\hline
\end{tabular}


Table 16 - continued from previous page

\begin{tabular}{|c|c|c|c|c|c|c|c|c|c|c|c|c|c|c|c|c|c|c|c|c|}
\hline \multirow[b]{2}{*}{ Variable } & \multirow[b]{2}{*}{ Obs } & \multicolumn{3}{|c|}{ All observations } & \multicolumn{4}{|c|}{$\begin{array}{c}\text { Treatment group } \\
\text { Dresden }\end{array}$} & \multicolumn{12}{|c|}{$\begin{array}{l}\text { Control group } \\
\text { erlin \& } \\
\text {-Stralsund }\end{array}$} \\
\hline & & Mean & Std.Dev. & Min & Max & Obs & Mean & Std.Dev. & Obs & Mean & Std.Dev. & Obs & Mean & Std.Dev. & Obs & Mean & Std.Dev. & Obs & Mean & Std.Dev. \\
\hline \multicolumn{21}{|c|}{ Additional variables } \\
\hline Social security GDR & 4335 & 0.43 & 0.50 & 0 & 1 & 446 & 0.42 & 0.49 & 3740 & 0.43 & 0.50 & 3457 & 0.44 & 0.50 & 862 & 0.43 & 0.50 & 978 & 0.45 & 0.50 \\
\hline Democracy GDR & 4334 & 0.42 & 0.49 & 0 & 1 & 447 & 0.40 & 0.49 & 3738 & 0.43 & 0.50 & 3455 & 0.44 & 0.50 & 862 & 0.47 & 0.50 & 978 & 0.46 & 0.50 \\
\hline Life GDR & 15028 & 0.23 & 0.42 & 0 & 1 & 1569 & 0.25 & 0.44 & 12984 & 0.23 & 0.42 & 12011 & 0.23 & 0.43 & 2934 & 0.21 & 0.41 & 3353 & 0.23 & 0.42 \\
\hline Happiness & 36095 & 0.53 & 0.50 & 0 & 1 & 3690 & 0.53 & 0.50 & 31246 & 0.53 & 0.50 & 28894 & 0.53 & 0.50 & 7170 & 0.53 & 0.50 & 8031 & 0.51 & 0.50 \\
\hline $\begin{array}{l}\text { Expected happiness in } \\
5 \text { yrs. }\end{array}$ & 35945 & 0.61 & 0.49 & 0 & 1 & 3681 & 0.65 & 0.48 & 31123 & 0.61 & 0.49 & 28785 & 0.61 & 0.49 & 7132 & 0.63 & 0.48 & 7990 & 0.60 & 0.49 \\
\hline Population density & 13467 & 405.37 & 895.88 & 52 & 3891 & 1341 & 229.95 & 86.66 & 11692 & 434.92 & 953.07 & & & & & & & & & \\
\hline $\begin{array}{l}\text { Inhabitants older than } \\
65\end{array}$ & 13467 & 15.74 & 1.59 & 12.4 & 19.1 & 1341 & 16.68 & 0.62 & 11692 & 15.69 & 1.63 & & & & & & & & & \\
\hline $\begin{array}{l}\text { Unemployment rate } \\
\text { (regional planning } \\
\text { unit) }\end{array}$ & 13467 & 18.05 & 2.88 & 6 & 23.4 & 1341 & 17.31 & 3.16 & 11692 & 18.08 & 2.83 & & & & & & & & & \\
\hline $\begin{array}{l}\text { Average industrial } \\
\text { wage }\end{array}$ & 13467 & 2007.29 & 340.25 & 1035 & 3835 & 1341 & 17.31 & 3.16 & 11692 & 2016.23 & 348.74 & & & & & & & & & \\
\hline GDR per capita & 13467 & 16.64 & 3.08 & 13.2 & 41.9 & 1341 & 16.59 & 3.62 & 11692 & 16.70 & 3.01 & & & & & & & & & \\
\hline Mother: Catholic & 7067 & 0.07 & 0.25 & 0 & 1 & 719 & 0.10 & 0.30 & 6043 & 0.07 & 0.25 & & & & & & & & & \\
\hline Mother: Protestant & 7067 & 0.32 & 0.47 & 0 & 1 & 719 & 0.32 & 0.47 & 6043 & 0.34 & 0.47 & & & & & & & & & \\
\hline Mother: Other & 7067 & 0.04 & 0.19 & 0 & 1 & 719 & 0.04 & 0.18 & 6043 & 0.04 & 0.19 & & & & & & & & & \\
\hline Mother: Not religious & 7067 & 0.57 & 0.50 & 0 & 1 & 719 & 0.55 & 0.50 & 6043 & 0.56 & 0.50 & & & & & & & & & \\
\hline $\begin{array}{l}\text { Respondent(1990): } \\
\text { Catholic }\end{array}$ & 33534 & 0.06 & 0.23 & 0 & 1 & 3311 & 0.08 & 0.27 & 29117 & 0.05 & 0.23 & & & & & & & & & \\
\hline $\begin{array}{l}\text { Respondent(1990): } \\
\text { Protestant }\end{array}$ & 33534 & 0.28 & 0.45 & 0 & 1 & 3311 & 0.26 & 0.44 & 29117 & 0.29 & 0.45 & & & & & & & & & \\
\hline $\begin{array}{l}\text { Respondent(1990): } \\
\text { Other }\end{array}$ & 33534 & .01 & 0.09 & 0 & 1 & 3311 & 0.01 & 0.12 & 29117 & 0.01 & 0.08 & & & & & & & & & \\
\hline $\begin{array}{l}\text { Respondent(1990): } \\
\text { Not religious }\end{array}$ & 33534 & 0.66 & 0.48 & 0 & 1 & 3311 & 0.64 & 0.48 & 33534 & 0.66 & 0.48 & & & & & & & & & \\
\hline Low household income & 1165 & 0.34 & 0.48 & 0 & 1 & 3652 & 0.26 & 0.44 & 28711 & 0.30 & 0.46 & & & & & & & & & \\
\hline $\begin{array}{l}\text { Intermed. household } \\
\text { income }\end{array}$ & 1165 & 0.34 & .48 & 0 & 1 & 3652 & 0.38 & 0.49 & 28711 & 0.38 & 0.49 & & & & & & & & & \\
\hline High household income & 1165 & 0.31 & 0.46 & 0 & 1 & 3652 & 0.36 & 0.48 & 28711 & 0.32 & 0.47 & & & & & & & & & \\
\hline
\end{tabular}




\section{Dependent variables}

Effort pays off

Luck

GDR media

Life GDR

Marx-Lenin

Socialist economies

Socialist democracy

Social security GDR

Democracy GDR

Life GDR

Happiness

Expected happiness in 5 yrs.
1: respondent states that a high level of effort pays off for the society as well as for oneself; 0 : otherwise

1: respondent states that what you achieve in life is mainly a matter of luck; 0 otherwise

1: respondent feels (very) well informed about the recent events by GDR press, radio and television; 0: otherwise

1: respondent likes living in the GDR; 0 otherwise

1: respondent agrees with Marxist-Leninist world view; 0: otherwise

1: respondent is confident in the economic development of socialist countries up to the year 2000.; 0: otherwise

1: respondent is confident in the development of socialist democracy in the GDR up to the year 2000.; 0: otherwise

1: respondent is satisfied with social security in the GDR; 0 otherwise

1: respondent is satisfied with the democracy in the GDR; 0 otherwise

1: respondent is (totally) satisfied with the general standard of living in the GDR; 0 otherwise

1: respondent is (totally) satisfied with life in general; 0 otherwise

1: respondent expects to be (totally) satisfied with general life in 5 years; 0 otherwise
GDR 1988/89

SOEP 1994-96, 1999

GDR $1988 / 89$

GDR 1988/89

GDR 1988/89

GDR 1988/89

GDR 1988/89

SOEP 1990

SOEP 1990

SOEP 1991-94

SOEP 1991-94

SOEP 1990-99

\section{Explanatory variables}

\section{Individual-level characteristics}

\section{Dresden}

Age

Female

Never married

Married

Widowed or divorced

Children

No. persons in household

No. children in household

University

High education

Intermed. education

Low education

Farther's education

Net income

Log. household income

Self-employed

Civil servant

Pensioner

Not employed

Unemployed

Unemployed

West Germany
1: respondent lives in the district of Dresden; 0 otherwise

1: respondent has lived in the district of Dresden in 1990; 0: in other parts of the GDR excl. Greifswald-Stralsund Age of the respondent

1: respondent is female; 0: otherwise

1: respondent has never been married (i.e. is single); 0 otherwise

1: respondent is married; 0: otherwise

1: respondent is either widowed or divorced; 0 otherwise

1: respondent has children; 0 otherwise

Number of persons living in the respondent's household.

Number of children living in the respondent's household.

1: respondent has an university degree; 0 otherwise

1: respondent has finished $12^{\text {th }}\left(13^{\text {th }}\right)$ grade; 0 otherwise

1: respondent has finished $10^{t h}$ (at least $9^{t h}$ ) grade; 0 otherwise

1: respondent has finished $8^{t h}\left(9^{t h}\right)$ grade or left school without a degree; 0 otherwise

Level of education of respondent's farther

Respondent's net income: 1 (500 Mark) - 9 (more than 1500 Mark)

Logarithm of respondent's yearly real available household income: 0 - 256,099 Euro

1: respondent is self-employed; 0 otherwise

1: respondent is a civil servant; 0 otherwise

1: respondent is a pensioner; 0 otherwise

1: respondent is not employment; 0 otherwise

1: respondent is unemployed; 0 otherwise

Total experience of unemployment until the survey year (in years)

1: respondent currently lives in West Germany; 0 otherwise
GDR 1988/89

SOEP 1990

GDR 1988/89; SOEP 1990-99

GDR 1988/89; SOEP 1990-99

GDR 1988/89; SOEP 1990-99

GDR 1988/89; SOEP 1990-99

GDR 1988/89; SOEP 1990-99

GDR 1988/89

SOEP 1990-99

SOEP 1990-99

GDR 1988/89; SOEP 1990-99

GDR 1988/89 (SOEP 1990-99)

GDR 1988/89 (SOEP 1990-99)

GDR 1988/89 (SOEP 1990-99)

SOEP 1990-99

GDR 1988/89

SOEP 1992-1999

SOEP 1990-99

SOEP 1990-99

SOEP 1990-99

SOEP 1990-99

SOEP 1990-99

SOEP 1990-99

SOEP 1990-99 


\section{Regional-level characteristics}

Population density

Industrial employment

Agricultural employment

Unemployment rate (state)

\section{Individual-level characteristics}

Inhabitants per $\mathrm{km}^{2}$ in the respondent's district

Industrial employment as a share of total employment

Agricultural employment as a share of total employment

Unemployment rate in the respondent's state of residence

GDR Statistical Yearbook 1990 GDR Statistical Yearbook 1989 GDR Statistical Yearbook 1989 INKAR (various years)

\section{Robustness tests}

1: respondent has visited a theater during the past month; 0 otherwise

1: respondent has visited a cinema during the past month; 0 otherwise

Theater

Cinema

Mother: Catholic

Mother: Protestant

Mother: Other

Mother: Not religious

Respondent (1990): Catholic

Respondent (1990): Protestant

Respondent (1990): Other

Respondent (1990): Not religio

Low household income

Intermed. household income

High household income

District-level characteristic

GDR-districts

Industrial production

Working age population

Working

High educated

Border district

Distance to Berlin
Theater visitors

1: respondent has visited a museum during the past month; 0 otherwise

1: respondent's mother is catholic; 0 otherwise

1: respondent's mother is protestant; 0 otherwise

1: respondent's mother is religious but neither catholic nor protestant; 0 otherwise

1: respondent's mother is not religious; 0 otherwise

1: respondent's stated to be catholic in 1990; 0 otherwise

: respondent's stated to be protestant in 1990; 0 otherwise

1: respondent's stated to be religious but neither catholic nor protestant in 1990; 0 otherwise

1. respondent's stated to be not relgious in 1990; 0 otherwise

1: In year 1990 and 1991 and respondent belongs in 1992 to the 25 percent with the lowest household income; 0 otherwise

1: In year 1990 and 1991 and respondent belongs in 1992 to the 50 percent with the medium household income; 0 otherwis

1: In year 1990 and 1991 and respondent belongs in 1992 to the 25 percent with the highest household income; 0 otherwise
GDR $1988 / 89$

GDR 1988/89

GDR 1988/89

SOEP 1990-1990

SOEP 1990-1990

SOEP 1990-1990

SOEP 1990-1990

SOEP 1990

SOEP 1990

SOEP 1990

SOEP 1990

SOEP 1990-91

SOEP 1990-91

FRG regional planning units

Population density

Inhabitants older than 65

Unemployment rate

Average industrial wage

GDP per capita

Industrial production of the district as a share of GDR total industrial production

Working age population as a share of total district population

Workers with university degree as a share of district working population

1: respondent lives in a district located at the inner-German border; 0 otherwise

Distance between the district capital and Berlin (in km)

Number of theater visitors as a percentage of total district population

Inhabitants per $\mathrm{km}^{2}$ in the respondent's regional planning unit

Inhabitants older than 65 as a share of total regional population

Unemployment rate in the respondent's region

Average gross wages in the respondent's region

GDP per capita in the respondent's region
GDR Statistical Yearbook 1989 GDR Statistical Yearbook 1989 Kind(1997)

GDR Statistical Yearbook 198

INKAR (various years)

INKAR (various years)

INKAR (various years)

INKAR (various years)

INKAR (various years) 